\title{
Underinvestment, Capital Structure and Strategic Debt Restructuring
}

\author{
Grzegorz Pawlina* \\ Department of Accounting and Finance, Lancaster University Management School, LA1 4YX, UK
}

\begin{abstract}
This paper shows that shareholders' option to renegotiate debt in a period of financial distress exacerbates Myers' (1977) underinvestment problem at the time of the firm's expansion. This result is a consequence of a higher wealth transfer from shareholders to creditors occurring upon investment in the presence of the option to renegotiate. This additional underinvestment is eliminated by granting creditors the entire bargaining power. In such a case, renegotiation commences at shareholders' bankruptcy trigger so no additional wealth transfer occurs. In addition to deriving the firm's policies, we provide results on the values of corporate claims, the agency cost of debt, and the optimal capital structure. Empirically, we predict, among others, a lower sensitivity of capital investment to shocks to Tobin's $q$ and cash flow for firms financed with renegotiable debt, and a negative effect of debt renegotiability on the relationship between growth opportunities and systematic risk as well as leverage.
\end{abstract}

Keywords: underinvestment, renegotiation, capital structure JEL classification: C61, D81, G31

\section{Introduction}

One of the consequences of debt financing is its influence on the firm's expansion policy. As it is known from Myers (1977), the presence of outstanding (risky) debt leads to underinvestment, that is, a situation in which some positive net present value (NPV) projects are foregone. ${ }^{1}$ Although the impact of debt on the firm's investment policy has been widely discussed in the literature, the existing contributions yield differing predictions concerning the effect of debt renegotiability upon default on investment (see Myers (1977), Mella-Barral and Perraudin (1997), and Mauer and Ott (2000)). In a unified dynamic model of a levered firm, we explicitly analyze how the possibility of debt renegotiation upon financial distress (before or after investment) affects the optimal exercise policy of the growth option.

\footnotetext{
*Phone: +44 1524 592834, fax: +44 1524 847321, email: g.pawlina@lancaster.ac.uk.

${ }^{1}$ For literature on debt overhang, see, for example, Myers (1977), Mello and Parsons (1992), Parrino and Weisbach (1999), Mauer and Ott (2000), Hennessy (2004), and Titman and Tsyplakov (2007).
} 
We show that the possibility of debt renegotiation upon default exacerbates the underinvestment problem at the times of the firm's expansion. This additional underinvestment increases with shareholders' bargaining power vis-à-vis creditors and is eliminated only if the entire bargaining power lies with lenders. Moreover, if equityholders hold at least some bargaining power, the investment delay increases with bankruptcy costs. As debt renegotiability is an inherent feature of private debt, our results clearly point out a disadvantage of private relative to public debt that has been so far omitted from the literature: private debt can make the underinvestment problem more severe. ${ }^{2}$ Moreover, as the possibility of debt renegotiation becomes more remote when the enforcement of creditors' rights improves (Favara et al. (2009)), investment is expected to be inefficiently delayed predominantly in legal systems in which the enforcement of debt contracts is weak. Empirically, we expect the investment level of firms financed with renegotiable debt to be less responsive to positive shocks to Tobin's $q$ and cash flow (earnings) compared to firms whose debt cannot be renegotiated. The differences in the corresponding coefficients are likely to be larger for firms in which the bargaining position of shareholders is stronger and bankruptcy costs are higher.

In the paper, we consider a firm run by shareholders and financed with perpetual debt. The firm generates a stochastic profit flow, which can be scaled up by incurring an irreversible investment cost. The timing of such an expansion is chosen by shareholders, who also bear its cost. At any time, shareholders can trigger debt restructuring by defaulting on the contractual coupon flow.

The exact nature of the restructuring process - formal bankruptcy or renegotiation - depends on the type of outstanding debt. Debt can be either non-renegotiable or renegotiable. Non-renegotiable debt would typically correspond to public debt, for which coordination problems make renegotiation prohibitively expensive (Rajan (1992), Hege and Mella-Barral (2005)), or to legal systems in which the enforcement of creditors' rights is strong (Favara et al. (2009)). In our model, default on non-renegotiable debt leads to bankruptcy. Renegotiable debt is associated with private (bank) debt (Berlin and Loeys (1988)), a concentrated creditor base (Bolton and Scharfstein (1996)), and with weak enforcement of debt contracts. Default on such debt is followed by renegotiation leading in equilibrium to a reduction of coupon payments.

The intuition underlying the mechanism of underinvestment is as follows (cf. Mauer and Ott (2000) and Hennessy (2004)). When expanding the firm, shareholders not only incur the investment cost but also face an erosion in the value of their option to default. Upon expansion (strategic) default becomes less attractive as it is now associated with the handover of a higher value of the firm to creditors than before expansion. Consequently, as investment makes the default option worth less, shareholders delay it until its NPV becomes sufficiently positive to compensate for the reduced option value.

What about the effect of debt renegotiability on the magnitude of underinvestment?

\footnotetext{
${ }^{2}$ The choice between the private and public debt has been explained in the literature by such factors as flotation costs, monitoring incentives of the lender (Diamond (1984)), borrower's reputation building (Diamond (1991)), efficient liquidation hypothesis (Berlin and Loeys (1988)) and the distortion of managerial incentives (Rajan (1992)).
} 
We know that shareholders prefer debt renegotiation to straight bankruptcy since they generally receive a strictly positive payoff in the former case and zero in the latter. Also, upon the firm's expansion, the (absolute) reduction in the value of the option to renegotiate is shown to be greater than of the option to go bankrupt. As a result, underinvestment is exacerbated by debt renegotiability. Furthermore, when shareholders have more bargaining power, their option to default is more valuable and its loss of value upon investment more significant. Consequently, in such a case, equityholders delay investment by more than they would if creditors had dominant bargaining power. Therefore, our second result follows: higher equityholders' bargaining power in debt renegotiation upon default results in more severe underinvestment at the times of a firm's expansion. Finally, the negative effect of debt renegotiability on investment is stronger when bankruptcy costs, which determine the surplus from renegotiation, are higher.

The paper makes therefore the following two main contributions. First, it identifies a cost of renegotiable debt that has so far been omitted from the literature: renegotiable debt can exacerbate the underinvestment problem. ${ }^{3}$ Second, it demonstrates that the investment inefficiency can be mitigated by taking the bargaining power away from equityholders. As such, it provides a rationale for a legal code that would favor creditors in a debt restructuring process (cf. Davydenko and Franks (2008)).

Our results provide a number of testable hypotheses. Among others, we expect debt renegotiability to strengthen the negative effect on investment of the debt overhang proxy (cf. Hennessy et al. (2007)). Debt renegotiability is also expected to reduce the effect on investment of positive cash flow (earnings) shocks. Furthermore, the effect of the growth options on the systematic risk of equity (Carlson et al. (2004)) is going to be muted if the firm is financed with renegotiable debt. As the underinvestment problem is expected to be most severe for firms with outstanding renegotiable debt, we also predict a negative impact of the interaction of debt renegotiability and growth opportunities on leverage.

Furthermore, we address the effect of the firm's growth option on its optimal debt restructuring policy. In general, the presence of a positive NPV project delays default as it makes its opportunity cost higher. However, the presence of such a project in combination with high debtors' bargaining power, is shown to result in an earlier timing of default on renegotiable debt. Finally, we discuss the effect of debt renegotiability on the values of corporate claims, the agency cost of debt, and the optimal capital structure.

A number of existing contributions can be nested in this paper's framework. Setting the coupon level equal to zero leads to the basic model of Dixit and Pindyck (1994) (see also McDonald and Siegel (1986)) with the firm scaling up its activities. Excluding the renegotiation possibility reduces the model to Mauer and Ott (2000). By setting the investment cost to infinity and liquidation value to zero, one arrives at Fan and Sundaresan (2000), whereas

\footnotetext{
${ }^{3}$ Although in Rajan (1992) renegotiable (private) debt also leads to inefficient investment (underinvestment in effort), the economics of our model is entirely different. In Rajan's paper, the owner-manager is reluctant to exert the optimal level of effort anticipating that the bank will hold her up when renewing financing for the project. In our paper, higher underinvestment occurs as equityholders take into account the more dramatic reduction in the value of the option to default.
} 
imposing a prohibitively high investment cost in combination with take-it or leave-it offers and no taxes reduces the model to Mella-Barral and Perraudin (1997).

Consequently, this paper builds upon Mauer and Ott (2000), who analyze the interaction between leverage and the investment option when renegotiation is not allowed for, and both Mella-Barral and Perraudin (1997), and Fan and Sundaresan (2000), who focus on strategic debt service. ${ }^{4}$ Following these contributions, we restrict the cost of debt restructuring to be a binary variable and do not limit its duration (see Hackbarth et al. (2002) and François and Morellec (2004) for the relevant extensions). ${ }^{5}$

The remainder of the paper is organized as follows. In Section 2 the model of the firm is described. Numerical results and comparative statics are presented in Section 3. Empirical implications are discussed in Section 4, whereas conclusions are provided in Section 5. Proofs of propositions are relegated to the Appendix.

\section{Model of a Levered Firm}

As a starting point, both the firm and the stochastic environment in which it operates are characterized. Subsequently, a dynamic valuation model of the firm following the exercise of the growth option is developed. Using this model, we calculate the values of the claims written on the firm's cash flows and derive the optimal debt restructuring and liquidation policies. These are used to derive results concerning the expansion policy of the firm.

\subsection{Cash Flow Dynamics}

Consider a firm that is run by a deep-pocket owner-manager (equityholders) maximizing the value of equity. The firm generates instantaneous cash flow $x_{t}$. The firm has an option to expand by incurring sunk cost $I$. After spending $I$, the firm is entitled to cash flow $\theta x_{t}$, with $\theta>1$. Let indicator $i \in\{0,1\}$ be equal to 0 if the growth option has not yet been exercised, and to 1 in the opposite case. The liquidation value of the firm is equal to $\gamma_{i}$.

All parties in the model are assumed to be risk-neutral and $r$ is the instantaneous riskless interest rate. ${ }^{6}$ The impact of economic uncertainty on the firm's cash flow is captured by letting $x_{t}$ follow a geometric Brownian motion

$$
\mathrm{d} x_{t}=\alpha x_{t} \mathrm{~d} t+\sigma x_{t} \mathrm{~d} w_{t}
$$

\footnotetext{
${ }^{4}$ In a related work, Mauer and Sarkar (2004), Sundaresan and Wang (2007), and Egami (2009) analyze the effect of debt financing on the exercise policy of a growth option. However, neither of the papers allows for the firm to be active prior to the option exercise. As a consequence, there is no initial debt outstanding and the debt overhang problem, which is the focus of the current paper, does not exist.

${ }^{5} \mathrm{~A}$ far from complete list of references includes Vercammen (2000), analyzing how bankruptcy, triggered by the assets value falling below the face value of the debt, influences investment, and Anderson and Sundaresan (1996), Mella-Barral (1999), and Acharya et al. (2006), analyzing the effect of debt renegotiability on the values of corporate claims. A related work by Fischer et al. (1989), Mauer and Triantis (1994), and Dangl and Zechner (2004), focuses on the optimal recapitalization policy.

${ }^{6}$ Alternatively, one could assume that the payout from the project is spanned by a portfolio of traded assets.
} 
where $\alpha$ and $\sigma$ correspond to the instantaneous growth rate and the volatility of the firm's cash flow, respectively, and $d w_{t}$ denotes a Wiener increment. We assume that $\alpha<r$ to obtain finite valuations, and denote the return shortfall, $r-\alpha$, by $\delta$.

\subsection{Payoffs upon Restructuring and Liquidation}

Cash flow of the firm is subject to tax rate $\tau$. The firm is financed with perpetual debt with coupon $b$, which is tax deductible. Because of the limited liability, it is optimal for equityholders to restructure debt in some states of nature. Equityholders restructure debt at trigger level $\underline{x}_{r_{i}}$ of cash flow process (1), which is chosen to maximize the value of equity. This modeling approach is consistent with, for instance, Leland (1994), Mella-Barral and Perraudin (1997), and Acharya and Carpenter (2002). Two types of debt restructuring upon default are analyzed: bankruptcy and debt renegotiation.

In the situation in which default triggers formal bankruptcy, the absolute priority rule (APR) is upheld and equityholders receive nothing. ${ }^{7}$ Once the firm is declared bankrupt, creditors foreclose its assets and act as its managers. Creditors are less efficient than shareholders when running the firm and the level of cash flow is $\rho \theta x$ provided the expansion option has been exercised and $\rho x$ if it has not been, with $\rho \in[0,1]$. It is assumed that it is not optimal for creditors to liquidate the firm immediately upon bankruptcy. A sufficient condition for this assumption to hold is $\gamma_{i} r<\rho \theta^{i-1} b(1-\tau) .{ }^{8}$ Such a restriction on the liquidation value implies that debt is risky. ${ }^{9}$ When cash flow process $x$ reaches a sufficiently low level, it becomes optimal for creditors to shut down the firm and to realize the liquidation value, $\gamma_{i}$. Furthermore, the investment opportunity is lost upon bankruptcy. This assumption follows the notion that creditors do not have human capital necessary for an economically viable execution of the investment project and that they face, as a group, a significant coordination problem in doing so. Finally, creditors cannot re-lever after foreclosing the firm's assets. ${ }^{10}$

The divergence between the value of the firm managed by shareholders and its value in the hands of creditors implies that there is a scope for debt renegotiation. Renegotiation allows for avoiding the following three components of the bankruptcy costs. First, the

\footnotetext{
${ }^{7}$ Evidence presented by Franks and Torous (1989) indicates significant departures from the absolute priority rule in many bankruptcy settlements. This assumption has been introduced for simplicity and without it bankruptcy would occur for higher realizations of cash flow.

${ }^{8} \mathrm{~A}$ superscript attached to a symbol always denotes an exponent unless it is placed in parentheses.

${ }^{9}$ Allowing for a set of parameter values for which creditor initiated liquidation occurs upon bankruptcy would not change the investment and default policies for a given coupon rate $b$ but would affect debt value and the ex ante choice of the optimal capital structure. As this assumption also rules out a situation in which equityholders prefer to liquidate the firm and repay $b / r$ to creditors, debt is risky. Sufficiently high liquidation values would result in riskless debt and efficient investment.

${ }^{10}$ This assumption is made only for an analytical convenience. For the results to hold, the firm run by creditors is assumed to satisfy at least one of the three following conditions: ( $i$ ) it cannot re-lever instantaneously so (a fraction of) the tax shield is lost upon bankruptcy, ( $\mathrm{i}$ ) if bankruptcy occurs prior to investment, the exercise price of growth option gets multiplied by a constant $\phi>1$ (e.g., to reflect the coordination problems among creditors), with a special case $\phi \rightarrow \infty$ meaning that the growth option expires unexercised, ( iii) debtholders will run the firm less efficiently, so that the cash flow generated by the firm in their hands equals $\rho \theta^{i}(1-\tau) x$, where $\rho \in(0,1)$.
} 
investment opportunity is preserved under renegotiation but not upon bankruptcy. Second, the inefficiency resulting from creditors managing the firm (and generating reduced cash flow $\rho x$ ) is avoided. Finally, the tax shield on debt is not irreversibly lost but only temporarily suspended.

\subsection{Debt renegotiation}

Following Mella-Barral and Perraudin (1997) and Fan and Sundaresan (2000), we allow for the possibility of renegotiating the coupon payment so that bankruptcy can be avoided and the surplus be split among equityholders and creditors. The renegotiation process is formalized as Nash bargaining in which bargaining power is split between the two groups of the firm's stakeholders (Fan and Sundaresan (2000), Christensen et al. (2002)). The distribution of bargaining power is captured by parameter $\eta \in[0,1]$. A high (low) value of $\eta$ is associated with high bargaining power of equityholders (creditors). High bargaining power of equityholders is expected for large corporations, and for firms with relatively low R\&D expenditures (Garlappi et al. (2008)). In contrast, small and young firms that use a portfolio of the bank's services and those for which an unexpected cash shortfall may impair the innovation process are likely to have a much weaker bargaining position. In addition, Davydenko and Strebulaev (2007) argue that the equityholders' incentives to exert effort in renegotiation increase with insider ownership. Their notion is supported by the empirical observation that deviations from the APR in Chapter 11 are significantly higher when managers have an equity stake in the firm (Betker (1995), LoPucki and Whitford (1990)). Finally, shareholders are expected to be more tough if institutional shareholdings are relatively high. This is due to the fact that coordinated and more sophisticated investors can bargain more effectively.

As debt renegotiation has a form of a strategic debt service, it is associated with a lower than contractual coupon payment. We follow Mella-Barral and Perraudin (1997) and Fan and Sundaresan (2000) in assuming that the coupon is a function of the current cash flow. ${ }^{11}$ Moreover, we impose the assumption made by Fan and Sundaresan (2000) that during the renegotiation process the tax shield is temporarily suspended. As soon as the cash flow from operations recovers and debtholders start receiving coupon $b$ again, the tax shield is restored. ${ }^{12}$ Therefore, the value of the firm as the bargaining object is endogenous to the choice of the renegotiation trigger. ${ }^{13}$

\footnotetext{
${ }^{11}$ This approach allows for avoiding path-dependency leading to analytical intractability. Hege and MellaBarral (2000) make an alternative assumption that a once-reduced coupon cannot be increased.

${ }^{12}$ According to Fan and Sundaresan (2000), p. 1072, the temporary tax shield suspension in the renegotiation region "may be interpreted as debtholders agree to forgive some debt and the Internal Revenue Service (IRS) suspends tax benefits until contractual payments are resumed." An alternative approach is proposed by Hege and Mella-Barral (2000), and Hackbarth et al. (2007), who assume that the magnitude of the tax shield corresponds to the prevailing coupon payment.

${ }^{13}$ The possibility of debt renegotiation at the exercise boundary of the growth option is precluded. This assumption can be motivated in the following way: suppose that there is a positive fixed cost of renegotiation (incl. the suspension of the tax shield) and the scale of a single expansion is not too large. In such a case, the benefits of renegotiation at an expansion threshold will not compensate for this cost. At the same time,
} 
As a result of bargaining, each party receives a fraction of the total firm value. First, the value of the firm as a function of the equityholders' renegotiation trigger is calculated and the optimal sharing rule is determined. Second, the values of debt and equity are derived, and the optimal equityholders' renegotiation and investment policies as well as the firm's optimal liquidation rule are determined.

To obtain the valuation of claims and the optimal equityholders' policies, the bargaining game needs to be solved. Denote the value of the firm by $V_{i}(x)$ and let $\varphi_{i}^{*}(x)$ be the outcome of the Nash bargaining process being equal to the fraction of the firm received by shareholders at cash flow level $x$. Consequently, shareholders receive $\varphi_{i}^{*}(x) V_{i}(x)$ and the debtholders obtain $\left(1-\varphi_{i}^{*}(x)\right) V_{i}(x)$. Fraction $\varphi_{i}^{*}(x)$ depends on the outside options of equityholders and debtholders, that is, the payoffs that both parties would receive if they decided to quit renegotiation. The outside options of equityholders and creditors are zero and $R_{i}(x)$, respectively, where $R_{i}(x)$ is the value of the assets when the firm is managed by creditors. Therefore, the solution of the bargaining game can be written as

$$
\begin{aligned}
\varphi_{i}^{*}(x) & =\underset{\varphi_{i}(x)}{\arg \max }\left[\left(\varphi_{i}(x) V_{i}(x)\right)^{\eta}\left(\left(1-\varphi_{i}(x)\right) V_{i}(x)-R_{i}(x)\right)^{1-\eta}\right] \\
& =\eta \frac{V_{i}(x)-R_{i}(x)}{V_{i}(x)}
\end{aligned}
$$

From (2) it can be concluded that the fraction of the firm received by equityholders in the renegotiation process critically depends on the creditors' outside option, $R_{i}(x)$. If $R_{i}(x)=0$ (that is, if $\gamma_{i}=\rho=0$ ), shareholders receive the fraction of the firm equal to their bargaining power coefficient. In the opposite case, that is, when the creditors' outside option equals the value of the firm $(\rho=1, \tau=0$, and $i=1)$, shareholders receive nothing.

The associated stream of coupon payments $b_{r_{i}}$ is exactly equal to fraction $\left(1-\varphi_{i}^{*}(x)\right)$ of the net cash flow in the renegotiation region or $b$ outside that region:

$$
b_{r_{i}}= \begin{cases}(1-\eta) x \theta^{i}(1-\tau)+\eta r \gamma_{i} & x \in\left(\underline{x}_{l_{i}}^{(1)}, \underline{x}_{l_{i}}^{(0)}\right] \\ (1-\eta(1-\rho)) x \theta^{i}(1-\tau) & x \in\left(\underline{x}_{l_{i}}^{(0)}, \underline{x}_{r_{i}}^{(1)}\right] \\ b & x>\underline{x}_{r_{i}}^{(1)} .\end{cases}
$$

The first regime of the strategic debt service corresponds to the earnings level remaining between the firm's optimal liquidation trigger, $\underline{x}_{l_{i}}^{(1)}$, and creditors' liquidation trigger, $\underline{x}_{l_{i}}^{(0)}$. In this case, creditors receive a weighted average of cash flow from holding the collateral, $r \gamma_{i}$, and from operating the firm efficiently, $x \theta^{i}(1-\tau)$. These streams are weighted with shareholders' bargaining power coefficient, $\eta$. For the earnings level above $\underline{x}_{l_{i}}^{(0)}$, but still in the renegotiation region, creditors receive a weighted average of cash flow from operating the

(costly) renegotiation at the lower boundary may still be optimal as its (positive) effect on the value of the firm is likely to be substantial. Consequently, ruling out renegotiation at the investment threshold is aimed to reflect a common situation in which a typical capital investment decision, and its potential departure from the first-best policy, is associated with much less significant valuation implications than a decision to default. 
company on their own, $x \rho \theta^{i}(1-\tau)$, and from serving as fully efficient managers, $x \theta^{i}(1-\tau)$. Outside the renegotiation region, the contractual coupon, $b$, is paid.

Note that for $\tau=0$ and $\eta \in\{0,1\}$, the coupon schedule corresponds to the outcome of the take-it or leave-it offers in Mella-Barral and Perraudin (1997), whereas setting $\gamma_{i}$ to zero reduces the solution to the payment scheme of Fan and Sundaresan (2000). Furthermore, the presence of the growth opportunity does not change the coupon flow to the creditors within any of the three regimes. This finding follows from the fact that the investment opportunity, which constitutes a part of the firm's value, is not associated with any payment stream.

To differentiate between the claims' values and policy triggers in the absence and in the presence of renegotiation, we have introduced indicator $k$ that assumes the value of 1 if renegotiation occurs upon default and 0 otherwise. For notational convenience, we assume that $\eta>0$ implies $k=1$ (when renegotiation is not allowed for, the distribution of bargaining power is irrelevant anyway).

\subsection{Valuation of Claims after Investment}

By observing that equityholders maximize the value of their claim when selecting the debt restructuring policy and that the liquidation policy maximizes the (remaining) value of the firm and by solving the system of corresponding value-matching and smooth-pasting conditions, one can formulate the following proposition. ${ }^{14}$

Proposition 1. Under the assumptions given above, the values of the firm, $V_{1}^{(k)}(x)$, tax shield, $T S_{1}^{(k)}(x)$, bankruptcy costs, $B C_{1}^{(k)}(x)$, equity, $E_{1}^{(k)}(x)$, and debt, $D_{1}^{(k)}(x)$, after investment is made are equal to

$$
\begin{aligned}
V_{1}^{(k)}(x) & =\frac{\theta x(1-\tau)}{\delta}+T S_{1}^{(k)}(x)-(1-k) B C_{1}(x)+L_{1}^{(k)} x^{\beta_{2}} & & \text { for } x>\underline{x}_{l_{1}}^{(k)} \\
& =\gamma_{1} & & \text { for } x \leq \underline{x}_{l_{1}}^{(k)} \\
E_{1}^{(k)}(x) & =\frac{\theta x(1-\tau)}{\delta}-\frac{b(1-\tau)}{r}+B_{1}^{(k)} x^{\beta_{2}} & & \text { for } x>\underline{x}_{r_{1}}^{(k)} \\
& =\eta\left[V_{1}^{(1)}(x)-R_{1}(x)\right] & & \text { for } x \leq \underline{x}_{r_{1}}^{(k)} \\
D_{1}^{(k)}(x) & =V_{1}^{(k)}(x)-E_{1}^{(k)}(x) & & \text { for all } x,
\end{aligned}
$$

where

$$
\begin{aligned}
T S_{i}^{(k)}(x) & =\frac{b \tau}{r}\left[1-\left(\frac{\beta_{1}}{\beta_{1}-\beta_{2}}\right)^{k}\left(\frac{x}{\underline{x}_{r}^{(k)}}\right)^{\beta_{2}}\right] & & \text { for } x>\underline{x}_{r_{i}}^{(k)} \\
& =k\left[\frac{b \tau}{r} \frac{-\beta_{2}}{\beta_{1}-\beta_{2}}\left(\frac{x}{\underline{x}_{r}^{(k)}}\right)^{\beta_{1}}\right] & & \text { for } x \leq \underline{x}_{r_{i}}^{(k)} \\
B C_{i}(x) & =\frac{(1-\rho) \theta^{i} x(1-\tau)}{\delta}\left(\frac{\max \left\{x, \underline{x}_{r}^{(0)}\right\}}{\underline{x}_{r_{i}}^{(0)}}\right)^{\beta_{2}-1} & & \text { for all } x
\end{aligned}
$$

\footnotetext{
${ }^{14}$ At the optimal equityholders' renegotiation trigger, the value of all claims remain differentiable. For the equity it is the result of the smooth-pasting condition that guarantees optimality of the trigger. For the value of the firm and its debt it is a no-arbitrage condition. Since the renegotiation process is reversible, i.e., equityholders will restore the original coupon flow, $b$, as soon as the earnings process again exceeds the critical threshold, $\underline{x}_{r_{1}}$, the first-order derivative of the value of all the claims must be continuous.
} 
and $\beta_{1}\left(\beta_{2}\right)$ is the positive (negative) root of the fundamental quadratic $\frac{1}{2} \sigma^{2} \beta(\beta-1)+\alpha \beta-$ $r=0 . R_{i}(x)$ denotes the value of the firm managed by creditors. The optimal debt restructuring and liquidation liquidation triggers, $\underline{x}_{r_{1}}$ and $\underline{x}_{l_{1}}$, are given by

$$
\begin{aligned}
\underline{x}_{r_{1}}^{(k)} & =\frac{-\beta_{2}}{1-\beta_{2}} \frac{b \delta(1-\tau+\eta \tau)}{(1-\eta(1-\rho)) \theta(1-\tau) r}, \\
\underline{x}_{l_{1}}^{(k)} & =\frac{-\beta_{2}}{1-\beta_{2}} \frac{\delta}{\rho^{1-k} \theta(1-\tau)}\left[\gamma_{1}-\frac{k b \tau}{r}\left(\frac{\underline{x}_{l_{1}}^{(1)}}{\underline{x}_{r_{1}}^{(1)}}\right)^{\beta_{1}}\right],
\end{aligned}
$$

respectively. Constants $B_{1}^{(k)}$, and $L_{1}^{(k)}$ are defined by equations (A.6) and (A.15) in the Appendix.

According to Proposition 1, which is in line with Fan and Sundaresan (2000), the value of the firm, $V_{1}(x)$, is the sum of the present values of cash flows, tax shield, $T S_{1}(x)$, and of the liquidation option, $L_{1} x^{\beta_{2}} \cdot{ }^{15}$ In a situation where bankruptcy occurs upon default, the value of the firm is reduced by the present value of bankruptcy costs, $B C_{1}(x)$. The value of equity is equal to the present value of cash flow from operations reduced by the present value of coupon payments and augmented with the debt restructuring option, $B_{1} x^{\beta_{2}}$. Following debt restructuring, the values of equity and debt are equal to the corresponding fractions of the firm value obtained according to the APR in case of bankruptcy upon default and to the optimal sharing rule (2) when renegotiation is allowed for. The value of debt can be simply calculated as the difference between the value of the firm and of its equity. The value of tax shield is a product of its present value if operated perpetually, $b \tau / r$, and the probability weighted discounted time of its operation (the value of which depends on the type of debt restructuring upon default). Finally, the value of the firm when managed by creditors, $R_{1}(x)$, is equivalent to $V_{1}^{(0)}(x)$ with bankruptcy having already occurred.

From (4) it follows that the optimal renegotiation threshold increases with equityholders' bargaining power, $\eta$, and decreases with creditors' efficiency in managing the firm's assets, $\rho$. When creditors have the entire bargaining power, optimal renegotiation threshold equals the bankruptcy trigger. In general, the optimal renegotiation trigger does not depend on liquidation value $\gamma_{1}$. This results from the fact that the change of the instantaneous payoff when the renegotiation commences is not influenced by the collateral. ${ }^{16}$

Equation (5) implies that, in the absence of taxes, the optimal liquidation trigger, $\underline{x}_{l_{1}}^{(1)}$, reduces to the exit threshold of an otherwise identical all-equity financed firm. For $\tau>$ $0, \underline{x}_{l_{1}}^{(1)}$ is lower than the all-equity threshold as the strictly positive present value of tax shield increases the opportunity cost of liquidation. Consequently, in the presence of taxes the liquidation option is exercised later when the firm is partially financed with debt and renegotiation is possible. In the absence of renegotiation, the firm is liquidated by creditors at a higher level of $x$ (cf. (5) with $k=0$ ).

\footnotetext{
${ }^{15}$ Superscript $(k)$ is omitted as long as doing so does not introduce any ambiguity.

${ }^{16}$ If $\gamma_{1}$ was high enough so that $R_{1}\left(x_{r_{1}}\right)=\gamma_{1}$, then the renegotiation trigger would depend on $\gamma_{1}$. However, this is ruled out by assumption. This result also is due to the special structure of optimal stopping problems that also underlies the main conclusions of Leahy (1993) and Baldursson and Karatzas (1997).
} 


\subsection{Valuation of Claims before Investment}

Following the derivation of the values of debt and equity after investment, it is possible to determine the optimal policies and calculate the claims' values before the expansion occurs. The derivation of the optimal investment threshold, $\bar{x}$, is done simultaneously with finding the optimal debt restructuring, $\underline{x}_{r_{0}}$, and liquidation, $\underline{x}_{l_{0}}$, triggers. The values of corporate securities before investment and the relevant policy triggers are found analogously as in Proposition 1, with additional value-matching and smooth-pasting conditions ensuring the continuity of the claim values at the investment threshold and reflecting the equityholders' choice of the expansion policy.

Proposition 2. Under the assumptions given above, the values of the firm, $V_{0}^{(k)}(x)$, its equity, $E_{0}^{(k)}(x)$, and debt, $D_{0}^{(k)}(x)$, before investment is made are equal to

$$
\begin{array}{rlrl}
V_{0}^{(k)}(x) & =\frac{x(1-\tau)}{\delta}+T S_{0}^{(k)}(x)-(1-k) B C_{0}(x) & \\
& +G_{v}^{(k)} x^{\beta_{1}}\left[1-(1-k)\left(\frac{\max \left\{x, \underline{x}_{0}^{(0)}\right\}}{\underline{x}_{r_{0}}^{(0)}}\right)^{\beta_{2}-\beta_{1}}\right]+L_{0}^{(k)} x^{\beta_{2}} & & \text { for } x>\underline{x}_{l_{0}}^{(k)} \\
& =\gamma_{0} & & \text { for } x \leq \underline{x}_{l_{0}}^{(k)} \\
E_{0}^{(k)}(x) & =\frac{x(1-\tau)}{\delta}-\frac{b(1-\tau)}{r}+G^{(k)} x^{\beta_{1}}+B_{0}^{(k)} x^{\beta_{2}} & & \text { for } x>\underline{x}_{r_{0}}^{(k)} \\
& =\eta\left[V_{0}^{(1)}(x)-R_{0}(x)\right] & & \text { for } x \leq \underline{x}_{r_{0}}^{(k)} \\
D_{0}^{(k)}(x) & =V_{0}^{(k)}(x)-E_{0}^{(k)}(x) & & \text { for all } x .
\end{array}
$$

The optimal investment threshold, $\bar{x}^{(k)}$, debt shareholders' restructuring trigger, $\underline{x}_{r_{0}}^{(k)}$, and liquidation trigger, $\underline{x}_{l_{0}}^{(k)}$, are given by the following equations:

$$
\begin{aligned}
\bar{x}^{(k)} & =\frac{\beta_{1}}{\beta_{1}-1} \frac{\delta I}{(\theta-1)(1-\tau)}+\frac{\beta_{1}-\beta_{2}}{\beta_{1}-1} \frac{\delta\left(B_{0}^{(k)}-B_{1}^{(k)}\right)\left(\bar{x}^{(k)}\right)^{\beta_{2}}}{(\theta-1)(1-\tau)}, \\
\underline{x}_{r_{0}}^{(k)} & =\frac{-\beta_{2}}{1-\beta_{2}} \frac{b \delta(1-\tau+\eta \tau)}{r(1-\tau)(1-\eta(1-\rho))}-\frac{\beta_{1}-\beta_{2}}{1-\beta_{2}} \frac{\delta\left(G^{(k)}-\eta G_{v}^{(k)}\right)\left(\underline{x}_{r_{0}}^{(k)}\right)^{\beta_{1}}}{(1-\tau)(1-\eta(1-\rho))}, \\
\underline{x}_{l_{0}}^{(k)} & =\frac{-\beta_{2}}{1-\beta_{2}} \frac{\delta}{1-\tau}\left[\gamma_{0}-\frac{b k \tau}{r}\left(\frac{\underline{x}_{l_{0}}^{(1)}}{\underline{x}_{r_{0}}^{(1)}}\right)^{\beta_{1}}\right]-\frac{\beta_{1}-\beta_{2}}{1-\beta_{2}} \frac{\delta G_{v}^{(k)}\left(\underline{x}_{l_{0}}^{(1)}\right)^{\beta_{1}}}{1-\tau} .
\end{aligned}
$$

Constants $B_{0}^{(k)}, G^{(k)}, G_{v}^{(k)}$, and $L_{0}^{(k)}$ are defined by equations (A.25), (A.29) and (A.31) in the Appendix.

[Please insert Figure 1 about here]

The values of equity, debt, and the total value of the firm for $k=1$ are depicted in Figure 1. In general, the value of the firm, $V_{0}(x)$, consists of five components: cash flow from operations, present value of tax shield, bankruptcy costs (positive for $k=0$ ) and the options 
to expand and to liquidate. The value of equity before debt restructuring is equal to the present value of cash flow from operations reduced by the value of riskless debt (net of the tax shield) and augmented by the options to expand and to renegotiate the debt contract. In the renegotiation region, the value of equity equals, again, the fraction of the firm value derived according to the sharing rule (2). The value of debt equals the difference between the total value of the firm and the value of equity.

From Proposition 2 it follows that investment, debt restructuring and liquidation triggers are affected by the the growth and bankruptcy options being interrelated. The first component of the expansion trigger (6) is simply equal to the optimal investment threshold of an all-equity firm (with no option to exit). The second component reflects the change in the value of the debt restructuring option upon the expansion $\left(B_{1} \bar{x}^{\beta_{2}}-B_{0} \bar{x}^{\beta_{2}}\right)$. As long as $B_{1}$ is different from $B_{0}$, the latter component is different from zero and the expansion policy of a debt financed company differs from the policy of an otherwise identical all-equity financed firm.

The optimal debt restructuring trigger of the firm is given by (7). Its first component equals the default trigger of an otherwise identical firm but without the growth option (cf. (4)). Its second component reflects the impact of the growth option on the timing of debt restructuring. A similar decomposition can be made for the liquidation trigger (8). In this case, the intuition is very simple: the opportunity cost of liquidation is higher when the growth option is present.

\subsection{Underinvestment and the Effect of Debt Renegotiability}

Before formulating the relevant proposition, we illustrate the mechanism of underinvestment with the following example. Assume that upon completing the investment project, the present value of the firm's cash flow will increase by $\$ 16$. The investment cost is $\$ 10$. The face value of debt is $\$ 14$ and it is assumed that equityholders declare bankruptcy if the present value of discounted future cash flow falls to $\$ 8$. The value of the option to default is $\$ 3$ (which is equal to the probability-weighted discount factor associated with the event of default, assumed to be 0.5 , times the payoff on default, $\$ 14-\$ 8=\$ 6$ ). After investment, cash flow is higher, so the probability of hitting the equityholders' optimal default boundary is lower (and assumed to be equal to 0.17). This results in a new value of the bankruptcy option, $\$ 1$. Consequently, the NPV of the investment project that accrues to the shareholders equals (in $\$$ ) $16-10-3+1=4$. Now, assume that the threshold profitability of the project at which irreversible investment is optimally made equals 1.5. Since the profitability of the project is $16 / 10=1.6$, investment should be undertaken. However, the presence of risky debt financing will lead to underinvestment as the equityholders will not exercise the investment opportunity at the current profitability level (from their viewpoint, the profitability of the project is only 1.4).

Proposition 3. Risky debt financing leads to underinvestment in the sense of the optimal equityholders' investment threshold $\bar{x}$ being higher that the optimal investment threshold $\bar{x}^{(e)}$ 
of an otherwise identical all-equity financed firm (with no abandonment options). Formally,

$$
\bar{x}>\frac{\beta_{1}}{\beta_{1}-1} \frac{\delta I}{(\theta-1)(1-\tau)} \equiv \bar{x}^{(e)} .
$$

Proposition 3, the proof of which is presented in the Appendix for the special case of $\tau=\gamma_{i}=$ 0 , is a direct implication of the debt restructuring option being worth less after the growth option is exercised than before the firm's expansion. In other words, equityholders not only incur the cost of expansion but also face a reduction of the value of their debt restructuring option (cf. Myers (1977)). The mechanism of the reduction in the option value to restructure debt can be explained using the following options analogy. Prior to investment, the debt restructuring option is equivalent (ignoring the interaction between options) to a put on the present value of perpetual cash flow $x$ (or the fraction $\left(1-\varphi_{i}^{*}\right)$ thereof when renegotiation is possible) with a strike price equal to $b(1-\tau) / r$. After investment, the strike remains the same but the put is written on the present value of $\theta x$ (or its corresponding fraction) received in perpetuity. Obviously, the value of the latter put option is lower. ${ }^{17}$

The intuition behind Proposition 3 follows from equation (6). When the possibility of debt restructuring exits, the optimal investment rule requires that the present value of the expansion project must be equal to the two following components. First, it has to compensate for the sunk cost, $I$, multiplied by markup $\beta_{1} /\left(\beta_{1}-1\right)(>1)$. Second, it has to compensate for the loss in option value to restructure debt, $\left(B_{0}-B_{1}\right) \bar{x}^{\beta_{2}}$, multiplied by markup $\left(\beta_{1}-\beta_{2}\right) /\left(\beta_{1}-1\right) .{ }^{18}$ (In fact, a similar mechanism based on interacting options influences the timing of debt restructuring (7) and of corporate liquidation (8).)

The markups can have a significant effect on the decision timing. When model parameters of Section $4(r=5 \%, \delta=4 \%$ and $\sigma=0.236)$ are adopted, an incremental dollar of an investment cost requires an additional 1.698/0.698 $\times \$ 1=\$ 2.43$ of the present value of the investment project to make the expansion worthwhile. Furthermore, a one-dollar loss in the option value to restructure debt requires an extra $(1.698-(-1.057)) / 0.698 \times \$ 1=\$ 3.95$ of the project value. (Similarly, one extra dollar gained upon debt restructuring and liquidation is needed to compensate for every foregone $\$ 0.51$ of the present value of cash flow and for every $\$ 0.38$ of the option value to expand.)

Now, the main proposition of the paper can be formulated.

Proposition 4. Strategic debt restructuring under financial distress exacerbates the underinvestment problem in the sense of the expansion option being exercised later than in the presence of bankruptcy occurring upon default.

\footnotetext{
${ }^{17}$ In fact, the two options differ only with respect to the initial price of the underlying and the latter option is more out of the money. The ratio of the option values (ignoring the interaction of the former with the growth option) is therefore equal to the discounted probability of cash flow falling from $\theta x$ to $x$, that is, to $\theta^{\beta_{2}}<1$.

${ }^{18}$ The latter markup is greater that the markup on the investment cost since $\beta_{2}<0$.
} 
In a situation where shareholders can renegotiate the debt contract, underinvestment is more severe than upon bankruptcy occurring upon default. This is a result of the fact that the option to renegotiate debt generally has a higher value than an analogous option to go bankrupt. Since the value of the option to restructure debt (i.e., either to renegotiate or to go bankrupt) decreases upon the firm's expansion, and the proportional reduction is similar across the two types of options (and is of the order of $\theta^{-\beta_{2}}$ ), the absolute reduction in the value of the renegotiation option must be higher than in the option value to go bankrupt (in fact, the latter difference is of the order of $\left(1-\varphi^{*}\right)^{\beta_{2}}\left(1-\theta^{\beta_{2}}\right)$ of the initial value of the bankruptcy option). To summarize, the higher magnitude of underinvestment with renegotiable debt is driven by a greater absolute reduction in the option value to restructure debt occurring upon the firm's expansion.

\subsection{Effect of Growth Opportunities on Liquidation and Strategic Default}

The growth option affects, through its impact on the value of equity and the firm as a whole, the optimal liquidation and debt restructuring policies. As far as its impact on the timing of liquidation is concerned, we obtain that

$$
\frac{\underline{x}_{l_{0}}}{\underline{x}_{l_{1}}} \geq \frac{\theta \gamma_{0}}{\gamma_{1}}
$$

with the equality holding for $k=0$ (the growth option is lost upon bankruptcy so it does not affect the liquidation policy even with no expansion having been made). For $k=1$, the presence of the growth option raises the opportunity cost of liquidating the firm. As a consequence, the firm is liquidated optimally at a cash flow level lower than $\gamma_{0} \theta \underline{x}_{l_{1}} / \gamma_{1}$.

The relationship between $\underline{x}_{r_{0}}$ and the debt restructuring trigger of an otherwise identical firm but without the growth option, $\theta \underline{x}_{r_{1}}$, is more subtle and, in general, ambiguous. Before expansion, the value of equity contains an additional component reflecting the value of the growth option. Other things being equal, this makes debt restructuring less attractive (so it would call for $\underline{x}_{r_{0}}$ being lower than $\theta \underline{x}_{r_{1}}$ ). In fact, this is exactly the outcome for $k=0$. However, for $k=1$, there is another opposing effect: it is possible that the value of the firm, as the object of bargaining, is higher when the investment opportunity is present. Therefore, from the perspective of equityholders, renegotiation can ceteris paribus become more attractive. Since these two effects work in opposite directions, the presence of the growth opportunity can, in general, either raise or lower the renegotiation trigger.

Proposition 5. The optimal strategic debt restructuring trigger in the presence of the investment opportunity can either be lower or higher than the corresponding trigger in a situation where the growth option is absent. The condition $\eta>\eta^{*}$ such that

$$
\eta^{*} G_{v}=G
$$

implicitly defines the range of parameter $\eta$ in which the presence of the investment opportunity results in earlier debt restructuring. 
From Proposition 5 it follows that in the presence of the growth option, renegotiation commences earlier than without the opportunity to expand if and only if the fraction of the growth option that accrues to shareholders under renegotiation, $\eta G_{v} x^{\beta_{1}}$, exceeds the current shareholders' value of the option to invest, $G x^{\beta_{1}} \cdot{ }^{19}$ This means that if bargaining power parameter $\eta$ is sufficiently high, it is optimal for shareholders holding the investment opportunity to begin renegotiation earlier than in the absence of the growth option. By doing so, shareholders forego the component of the value of equity associated with the expansion option but they are more than compensated by receiving a fraction of the firm's value including the total value of the growth option (i.e., the sum of the fractions of the value of the investment opportunity that accrue to equityholders and creditors). If debt restructuring has a form of bankruptcy, the presence of the growth option always delays the equityholders' decision to default.

This finding has a direct implication for the credit risk analysis. Namely, the presence of an additional asset (the growth option) when its value in the first-best use (i.e., when held by equityholders) substantially exceeds its value in the second-best use (i.e., when held by creditors) can reduce the firm's distance to default if strategic default is allowed for.

\section{Numerical Results}

This section presents numerical results and comparative statics concerning the firm's optimal policies, the values of its claims, agency costs, and the optimal capital structure choice. Our basic set of parameters is to reflect a typical US non-financial firm. Interest rate $r$ is $5 \%$, which is consistent with the long-term after tax interest rate (see Strebulaev (2007)). The return shortfall is assumed to equal 4\%, which is consistent with the long-term payout ratio reported by Grullon and Michaely (2002). Volatility parameter $\sigma$ equals 0.236 , which is the average asset volatility based on the sample of Eom et al. (2004) and the asset volatility of firms with A-rated bonds reported in Davydenko and Strebulaev (2007). The tax advantage of debt equals 0.1875 and is based on Graham (2000). ${ }^{20}$ The efficiency of creditors as the users of the firm's assets, $\rho$, is assumed to equal 0.63 , which is the lower bound of estimates reported in Alderson and Betker (1996). ${ }^{21}$ Furthermore, in the base case scenario the assumption of $\eta=0.75$ is adopted. ${ }^{22}$

\footnotetext{
${ }^{19}$ Obviously, condition (11) never holds for bankruptcy occurring upon default (the LHS is zero, as $k=0$ implies $\eta=0$, and its RHS is always positive).

${ }^{20}$ The tax advantage of debt is $\tau=1-\frac{\left(1-\tau_{c}\right)\left(1-\tau_{e}\right)}{1-\tau_{p}}=1-((1-0.12)(1-0.35)) /(1-0.296)$, where $\tau_{c}$, $\tau_{e}$, and $\tau_{p}$ denote the marginal corporate tax rate, tax rate on equity income and interest income tax rate, respectively. Once we allow for the personal taxes in our model, $b$ is the after-tax coupon, $r$ - the after-tax interest rate, and $x$ - the gross cash flow of the firm scaled down by $\left(1-\tau_{p}\right)$.

${ }^{21}$ In fact, for $\eta=0.5$, creditors' efficiency $\rho$ equal to 0.63 would correspond to the average recovery rate of 0.37 reported by Eckbo and Thorburn (2008) for bankruptcy auctions conditional on a going-concern sale.

${ }^{22}$ The mean value of the estimate of shareholder bargaining power in the recent paper by Morellec et al. (2008) is 0.457 . We decided to adopt a higher value of $\eta$ in the base case scenario, as these are the firms with dominant shareholders' bargaining power that are likely to face the additional underinvestment problem analyzed in the paper. When deriving the expansion policy, agency costs and the optimal capital structure, we allow this parameter to vary.
} 
The remaining six parameters of the model are implied from the real-world variables using the following four relationships and two additional conditions (on the ratio of liquidation values before and after the expansion and market capitalization).

\begin{tabular}{ll}
\hline Tobin's $q$ & $\left(D\left(x_{0}\right)+E\left(x_{0}\right)\right) /(I /(\theta-1))$ \\
Debt Value/Firm Value & $D\left(x_{0}\right) /\left(D\left(x_{0}\right)+E\left(x_{0}\right)\right)$ \\
Credit Spread & $b / D\left(x_{0}\right)-r$ \\
Liquidation Value/Face Value of Debt & $\left(P\left(x_{0}\right) \gamma_{0}+\left(1-P\left(x_{0}\right)\right) \gamma_{1}\right) /(b / r)$ \\
\hline
\end{tabular}

Tobin's $q$, which is the ratio of the market value of the firm's capital stock over its replacement value, is assumed to equal 2.49 , that is, the mean value in the Compustat industrial files between 1968 and 2003, as reported in Hennessy et al. (2007). ${ }^{23}$ The ratio of debt value to the market value of the firm is 0.33 , which is equal to the mean leverage ratio in Bernanke et al. (1990) and close to 0.36 obtained by Strebulaev (2007). Credit spread is assumed to be equal to 81 basis points, which is equivalent to the mean spread in the sample of A-rated bonds in Davydenko and Strebulaev (2007). The ratio of liquidation value to the face value of debt is equal to 0.26 and is based on the average recovery rate in a bankruptcy auction conditional on piecemeal liquidation, as reported by Eckbo and Thorburn (2008). As in our model the liquidation value depends on whether expansion has already taken place, we use an average of liquidation values before and after the expansion, weighted with the probabilities $\left(P\left(x_{0}\right)\right.$ and $1-P\left(x_{0}\right)$, respectively) of each of the scenarios occur. ${ }^{24}$ Moreover, we assume that liquidation values are proportional to the cash-flow generating ability of assets, that is, that $\gamma_{1}=\theta \gamma_{0}$. Finally, we impose the additional condition that the market capitalization of the firm is US\$100 million, which approximately equals the capitalization of the median US non-financial firm in the Compustat universe.

To obtain the model parameter values $b, I, x_{0}, \gamma_{0}, \gamma_{1}$, and $\theta$, we solve the system of equations of Proposition 2 augmented for the four conditions based on the values of observables (Tobin's q, Debt Value/Firm Value, Credit Spread, and Liquidation Value/Face Value of Debt) and the two additional conditions on the ratio of liquidation values before and after the expansion and market capitalization. As a consequence, the (unobservable) six parameters of the model are determined simultaneously with the decision thresholds and claim values. ${ }^{25}$ The resulting values for these parameters as well as for the thresholds and values are as follows (all the monetary values are denominated in US\$ million).

\footnotetext{
${ }^{23}$ Our model is in fact silent about the capital stock installed, so we base the replacement value of the firm's assets in place on the characteristics of the available expansion project. As the additional cash flow $(\theta-1) x$ is associated with investment cost $I$, the current level of cash flow $x$ is assumed to be generated with assets with the replacement value of $I /(\theta-1)$.

${ }^{24} P\left(x_{0}\right)$ is the probability of hitting $\underline{x}_{l_{0}}$ before hitting $\bar{x}$ starting from $x_{0}$. It is given by $P\left(x_{0}\right)=\frac{x_{0}^{\nu}-\bar{x}^{\nu}}{\left(\underline{x}_{l_{0}}\right)^{\nu}-\bar{x}^{\nu}}$ with $\nu \equiv-\frac{2 \alpha}{\sigma^{2}}+1$. If $\bar{x}$ is hit first, liquidation at $\underline{x}_{l_{1}}$ occurs with probability 1 as for a geometric Brownian motion with drift rate $\alpha=0.01<0.028=0.5 \sigma^{2}$ the probability of wandering off to infinity is zero. See also Dixit (1993).

${ }^{25}$ As the model is homogenous of degree 1 in $b, I, x_{0}, \gamma_{0}$, and $\gamma_{1}$, the multiplication of these parameters by a constant allows to re-interpret the results for a firm of a different size.
} 


\begin{tabular}{ll}
\hline$b=2.862$ & $\bar{x}=7.674$ \\
$I=49.981$ & $\underline{x}_{r_{0}}=1.778$ \\
$x_{0}=5.001$ & $\underline{x}_{l_{0}}=0.214$ \\
$\gamma_{0}=9.236$ & $E\left(x_{0}\right)=100$ \\
$\gamma_{1}=16.936$ & $D\left(x_{0}\right)=49.254$ \\
$\theta=1.834$ & $V\left(x_{0}\right)=149.254$ \\
\hline
\end{tabular}

Unless stated otherwise, these parameter values are used in the subsequent numerical illustrations.

\subsection{Optimal Policies}

The major finding concerning the impact of the renegotiability of debt on the expansion policy is that the option to restructure debt in a period of financial distress exacerbates Myers' (1977) underinvestment problem. A larger magnitude of underinvestment means that the growth option is exercised later than in the absence of the option to renegotiate (see Figure 2, Panels A-C). For the basic set of parameter values, cash flow level $\bar{x}^{(1)}=7.674$ triggers investment if debt is renegotiable, whereas $\bar{x}^{(0)}=7.445$ is already sufficient to trigger expansion otherwise.

[Please insert Table 1 about here.]

The comparative statics for the optimal investment, debt restructuring, and liquidation policies are depicted in Table 1 . Some of the results are consistent with those known from the real options literature (McDonald and Siegel (1986), Dixit and Pindyck (1994), Ch. 6), structural valuation of corporate debt pricing (Leland (1994, 1998), Mella-Barral and Perraudin (1997), Fan and Sundaresan (2000)), and on investment under debt financing (Mauer and Ott (2000), Titman and Tsyplakov (2007), Hennessy (2004), and Moyen (2007)). Therefore, in the remainder of the section, we focus on those results that are novel to this paper.

[Please insert Figure 2 about here.]

(i) The magnitude of underinvestment increases with book leverage, measured as the instantaneous coupon flow $b$. This result holds for both bankruptcy and renegotiation occurring upon default (see Figure 2, Panel A). ${ }^{26}$

(ii) The magnitude of additional underinvestment following from the renegotiability of debt is positively related to the equityholders' bargaining power $\eta$ (see Figure 2, Panel B). For example, the change from $\eta=0.1$ (dominant bargaining power of creditors)

\footnotetext{
${ }^{26}$ To compare, the optimal threshold under the first-best investment policy (that is, the policy that maximizes the total value of the firm) decreases with leverage and is lower than that of the all-equity financed firm. The latter result is due to the fact that investment not only augments the firm's cash flow but also enhances the present value of tax shield and reduces the economic cost of default.
} 
to $\eta=0.9$ (dominant bargaining power of equityholders) results in an increase of the expansion threshold from 7.464 to 7.767 . This relationship follows from the negative change in the option value to renegotiate, which occurs upon investment, being larger (in absolute terms) for higher values of $\eta \cdot{ }^{27}$

Obviously, shareholders' bargaining power has no impact on the investment policy of a firm whose debt is non-renegotiable (see $\bar{x}^{(0)}$ and $\bar{x}^{(0, f)}$ in Figure 2, Panel B).

(iii) The effect of creditors' outside option, captured by their efficiency parameter $\rho$, is illustrated in Panel $\mathrm{C}$ of Figure 2. Higher efficiency of creditors as the potential owners-managers of the firm reduces the equityholders' value of renegotiation. As a consequence, the absolute difference in the values of the option to renegotiate before and after investment is smaller, which results in lower underinvestment. For example, for the basic set of parameter values an increase in $\rho$ from 0.1 to 0.9 would result in the reduction of the expansion threshold from 8.154 to 7.574 .

Again, for non-renegotiable debt, $\rho$ has no impact on the expansion policy pursued by equityholders. ${ }^{28}$

(iv) The effect of the growth option on the renegotiation trigger is, in general, ambiguous and crucially depends on the equityholders' bargaining power, $\eta$ (see Proposition 5). For most values of $\eta(\eta<0.94$ for the basic set of parameter values), the presence of the growth option negatively influences the equityholders' willingness to engage in debt renegotiation. However, if shareholders expect to extract most of the bargaining proceeds ( $\eta$ close to 1 ), they commence renegotiation earlier since the growth option enhances the value of the firm as the bargaining object.

\subsection{Valuation of Securities}

As long as shareholders' bargaining power parameter $\eta$ is strictly positive, the option to renegotiate enhances the value of equity. This property follows from the fact that shareholders can do in the process of renegotiation at least as well as in the case of bankruptcy occurring upon default.

Equityholders' option to renegotiate may adversely affect the value of debt. This outcome occurs when the renegotiation trigger is considerably higher than the bankruptcy threshold of an otherwise identical firm but financed with non-renegotiable debt and the financial position of the firm (measured by $x_{0}$ ) is sound. For example, for the basic set of parameter values the value of renegotiable debt $D\left(x_{0}\right)$ is US $\$ 49.254$ million. If an otherwise

\footnotetext{
${ }^{27}$ If the timing of investment was chosen so as to maximize the value of the firm financed with renegotiable debt, the optimal investment threshold would decrease with $\eta\left(\right.$ see $\left.\bar{x}^{(1, f)}\right)$ due to the higher value of the tax shield.

${ }^{28}$ Creditors' efficiency $\rho$ positively influences the optimal investment threshold when the expansion policy is chosen so to maximize the total value of the firm. When debt renegotiation becomes more remote, the present value of additional tax shield due to investment becomes smaller. Consequently, other things being equal, investment becomes less attractive. Since higher $\rho$ reduces the probability of renegotiation, it also raises the investment threshold.
} 
identical firm was financed with non-renegotiable debt, the value of creditors' claim would be higher by US\$1.291 million, that is, by $2.62 \%$. On the other hand, for $x_{0}$ close enough to the bankruptcy trigger, allowing for renegotiation increases the value of debt since creditors' share of the firm received upon renegotiation is worth more than their claim upon bankruptcy.

Table 2 depicts the direction of the effects of model parameters on the valuation of equity, debt and the firm as a whole.

[Please insert Table 2 about here.]

$(v)$ The interaction between the options to invest and to renegotiate can influence the value of debt in both directions. If equityholders' bargaining power is so high that renegotiation commences earlier when the growth option is present (see Proposition 5), then the growth option can reduce the value of debt. Nevertheless, for most parameter configurations, the value of renegotiable debt is augmented by the presence of the growth option, due to a lower probability of strategic default.

\subsection{Agency Cost of Debt and Incremental Debt Overhang}

The ex post departure from the first-best investment policy results in a higher cost of debt at the time of its issuance. This higher cost, in turn, leads to a lower ex ante value of the firm. The presence of the option to renegotiate the debt contract can exacerbate the agency cost of debt. ${ }^{29}$

We measure the agency cost of debt, $A C(x)$, as the difference between the firm values under the first-best and the equity value-maximizing investment policies. In the absence of taxes and bankruptcy costs, the agency cost equals the reduction of the value of the firm in relation to an otherwise identical all-equity financed firm.

Since the main focus of this subsection is to investigate the magnitude of the agency cost of debt related to the underinvestment problem, we use the default trigger of the firm pursuing the optimal investment policy as the default trigger of the firm's investment policy that maximizes the equity value. Such a choice allows for isolating the effect of differing firstand second-best investment policies from the effect of differing debt restructuring policies (as in Mauer and Ott (2000)). ${ }^{30}$

Top two rows of Table 3 describe the signs of sensitivities of the agency cost of debt to changes in model parameters. The third row of Table 3 describes changes in the agency cost of renegotiable debt in relation to analogous changes associated with a debt contract that cannot be renegotiated.

\footnotetext{
${ }^{29}$ The agency costs of debt have been analyzed in the literature in the context of investment decisions for the case of shareholders' propensity to change riskiness of the firm's assets (Leland (1998), Ericsson (2001), and Subramanian (2007)), and the timing of investment (Mauer and Ott (2000)), and considered non-renegotiable debt.

${ }^{30} \mathrm{In}$ fact, this restriction potentially induces a bias against finding the agency cost. This is due to the fact that the equityholders' default options are not exercised optimally in the second-best case, which in principle reduces the equityholders' opportunity cost of expansion and, as a consequence, their optimal investment threshold.
} 
[Please insert Table 3 about here.]

An increase in leverage raises the agency cost of debt since the magnitude of the deviation from the firm value-maximizing investment policy increases with a higher proportion of debt. Moreover, changes in coupon rate $b$ have a similar first-order effect on the agency cost of both renegotiable and non-renegotiable debt.

Equityholders' bargaining power coefficient $\eta$ influences the agency cost of renegotiable debt through its positive impact on the renegotiation trigger. Consequently, the agency cost of debt due to underinvestment increases since equityholders become more reluctant to forego a fraction of the (higher) option value to renegotiate. With non-renegotiable debt, the bargaining power coefficient does not play any role since it does not affect the optimal investment trigger.

Creditors' ability to manage the firm's assets, $\rho$, reduces the agency cost of both kinds of debt. For non-renegotiable debt, higher $\rho$ reduces the present value of inefficiencies arising when the firm becomes managed by the creditors. For renegotiable debt, in addition, an increase in $\rho$ negatively influences the probability of strategic default. Therefore, the reduction in the agency costs which results from higher $\rho$ is greater for renegotiable debt.

The moneyness of growth options, measured by both $\theta$ and the inverse of $I$, exacerbates the agency cost of debt. This is due to larger differences in the present values of cash flows before and after investment under first- and second-best policies. This effect is generally stronger for renegotiable debt since $(i)$ the growth option contains not only the right to acquire higher cash flows but also a right to reduce the possibility of debt restructuring, and (ii) for strategic default, the latter possibility is of much higher importance. ${ }^{31}$

Panels A and B of Figure 3 illustrate the magnitude of the agency cost of renegotiable and non-renegotiable debt attributed to underinvestment as a function of the cash flow variable $x$. It can be seen that the renegotiability of the debt contract can substantially increase this cost. In the first case, we use the basic set of parameter values (Panel A). In the second scenario, we consider a firm operating in a declining and less volatile industry, with $\delta=\sigma=0.1$, in which (strategic) default is more likely and the option values of waiting are lower (Panel B).

[Please insert Figure 3 about here.]

In the basic scenario, for cash flow level $x_{0}=5.001$ the agency cost of debt induced by the underinvestment problem equals $\$ 0.181$ million. The maximum cost in this scenario amounts to $\$ 0.322$ million and occurs for $x=7.044$. The agency cost of debt highly depends on equityholders' bargaining power. If equityholders can extract most of the surplus from bargaining, the agency cost is relatively high. For $\eta=0.9$ the maximum magnitude of the

\footnotetext{
${ }^{31}$ In addition, the agency cost of debt decreases with cash flow volatility as a result of the investment threshold being higher for both kinds of debt. Furthermore, it is positively related to the return shortfall, $\delta$, and negatively related to the riskless rate, $r$. This is due to the fact that the probability of debt restructuring increases with $\delta$ (decreases with $r$ ) so timely investment becomes more (less) important for reducing the expected cost of default.
} 
agency cost of debt is $\$ 0.449$ million. Conversely, the agency cost of debt with creditors having more bargaining power $(\eta=0.1)$ is low and equals up to a modest $\$ 0.114$ million. To compare, the agency cost of debt for the non-renegotiable contract can reach $\$ 0.239$ million. In fact, if creditors can make take-it or leave-it offers, the agency cost is the lowest and always below the level corresponding to non-renegotiable debt.

The relationship between $A C^{(0)}$ and $A C^{(1)}$ can be explained as follows. For $\eta=0$, the investment and default policies associated with renegotiable debt are the same as with a non-renegotiable contract. For the same investment and default policies the agency cost of non-renegotiable debt is higher because of the bankruptcy costs associated with default. Therefore, if creditors hold the entire bargaining power, $A C^{(1)}$ is smaller than $A C^{(0)}$. As equityholders' bargaining power increases, a second effect comes into play - underinvestment becomes more severe. In fact, a level of $\eta$ exists for which there is no advantage of renegotiable debt anymore as the effect of additional underinvestment offsets the benefit of avoiding costly bankruptcy. For values of parameter $\eta$ above this level, the effect of higher underinvestment dominates and $A C^{(1)}$ exceeds $A C^{(0)}$.

An observation that is immediately made upon comparing Panels A and B of Figure 3 is that the agency cost of debt is much more severe when the dynamics of the firm's operating cash flow exhibits a relatively large return shortfall and low volatility. For example, the maximum agency cost of debt in the basic case $(\$ 0.322$ million, which translates into $0.14 \%$ of the firm value) is dwarfed by an impressive $\$ 3.377$ million, or $4.52 \%$ of the firm value, in the negative growth-low volatility scenario. The cost for $\eta=0.9$ is even higher and amounts to $\$ 3.797$ million. This result is explained by the fact that an excessive delay in making a value-enhancing investment in a declining industry with a little chance of a reversal in the trend may result in the investment not being undertaken at all.

To quantify the effect of debt renegotiability on the firm value that comes entirely from its impact on the investment policy, we introduce a measure of incremental debt overhang, IDO. $I D O$ is defined as the difference between the value of the firm financed with renegotiable debt but which pursues the investment policy of an otherwise identical firm but financed with nonrenegotiable debt and the value of the firm financed with renegotiable debt. Consequently, incremental debt overhang captures the effect of the additional investment delay resulting from debt renegotiability on the firm value. The signs of sensitivities of the incremental debt overhang to changes in model parameters are presented in the bottom row of Table 3. Similar to the agency cost of renegotiable debt, incremental debt overhang increases with the coupon rate, equityholders bargaining power, return shortfall and the moneyness of the growth option. Just like $A C^{(1)}, I D O$ decreases with creditors efficiency as users of the firm's assets, cash flow volatility and the interest rate.

The magnitude of incremental debt overhang is shown as a function function of the cash flow variable $x$ in Panels C (basic scenario) and D (negative growth-low volatility scenario) of Figure $3{ }^{32}$ In the basic scenario (for $x_{0}=5.001$ ), incremental debt overhang translates into a reduction of firm value of $\$ 0.097$ million. The maximum incremental overhang amounts

\footnotetext{
${ }^{32}$ Agency costs are differentiable for any $x$ lower than the second-best threshold $\bar{x}^{(k)}$ as the firm value is differentiable at the first-best investment threshold $\bar{x}^{(k, f)}\left(<\bar{x}^{(k)}\right)$. Incremental debt overhang exhibits a
} 
to $\$ 0.197$ million and occurs for $x=7.445$. As expected, higher equityholders' bargaining power exacerbates the debt overhang problem. For $\eta=0.9$ the maximum magnitude of $I D O$ is $\$ 0.303$ million. When it is creditors' bargaining power that is high $(\eta=0.1)$, incremental debt overhang is almost negligible since the investment policy becomes very close to the one of the firm financed with non-renegotiable debt. IDO equals then up to $\$ 0.012$ million.

Analogously as with the agency cost, incremental debt overhang is much more severe when the firm's operating cash flow exhibits a large return shortfall and low volatility. The maximum IDO in such a scenario equals $\$ 1.782$ million, or $2.03 \%$ of the firm value, for $\eta=0.75$ and $\$ 2.264$ million (2.59\% of the firm value) for $\eta=0.9$. Again, the incremental debt overhang is much higher for the negative growth-low volatility scenario as any additional delay in investment may result in the growth option being never exercised. Despite being optimal for equityholders, foregoing the expansion in such a case is detrimental to the firm value.

The results of our analysis indicate that higher flexibility of renegotiable debt does have its cost. Shareholders' inability to pre-commit to the optimal investment policy, or (at least) to the policy pursued with non-renegotiable debt financing, results in a potentially higher ex ante cost of debt.

\subsection{Optimal Capital Structure and Debt Capacity}

The presence of the renegotiation option affects the optimal capital structure in two opposite ways (see Fan and Sundaresan (2000)). On the one hand, the possibility of avoiding bankruptcy costs works towards increasing optimal leverage. On the other hand, the loss of the tax shield in the region of strategic debt service impairs the firm's ability to increase its value through further increases in the debt level. The trade-off between these two effects is strongly influenced by the presence of the growth opportunity.

A higher proportion of the growth option component in the firm's total value generally reduces the optimal market leverage (defined as the ratio of the value of debt and the total value of the firm). This is a result of the debt capacity of growth options (measured as the incremental optimal debt associated with an additional asset, see Barclay et al. (2006)) being lower than the debt capacity of assets in place. Consequently, market leverage of the firm with the growth option is lower than the optimal leverage of an otherwise identical firm but with assets in place only. Introducing the option to renegotiate the debt contract generally amplifies the negative impact of the growth option on the optimal leverage level (see Table 4 , columns $\Delta L E V^{(0)}$ and $\left.\Delta L E V^{(1)}\right)$.

[Please insert Table 4 about here.]

Similarly as in Leland (1994), Fan and Sundaresan (2000), and Mauer and Ott (2000), the optimal coupon rate increases with the current value of the project, $x_{0}$, the riskless rate, $r$, the tax rate, $\tau$, and the creditors' efficiency parameter, $\rho$ (see Table 4). Moreover, it

$\overline{\text { kink at the non-renegotiable threshold } \bar{x}^{(0)}}\left(<\bar{x}^{(1)}\right)$ as this threshold does not maximize the overall value of the firm. 
decreases when return shortfall $\delta$ high and (for renegotiable debt) when cash flow volatility $\sigma$ is low. Moreover, the optimal leverage decreases with equityholders' bargaining power parameter $\eta$.

When debt is renegotiable, introducing the growth option reduces the leverage most dramatically for high levels of earnings $x_{0}$, and for high moneyness of the growth option (low $I$ ). The interaction between the growth and debt renegotiation options appears to be the main driving force of a lower optimal leverage when equityholders bargaining power is high. In the basic case, the presence of the growth option reduces the optimal leverage by 11.77 percentage points. In contrast, when creditors have much say in the debt restructuring process $(\eta=0.25)$, the growth option does not have a big effect on market leverage in the optimum - the reduction is a mere $5.04 \%$.

The results of this section therefore indicate that low market leverage (cf. Graham (2000) and Morellec (2004)) may be to a certain extent attributed to the interaction of their growth options with the strategic default option. The negative joint effect of the growth option and debt renegotiability is namely shown to be stronger than a simple superposition of the effects of the growth option and debt renegotiability. In other words, leverage is expected to be negatively correlated with the interaction term of a proxy for growth opportunities (such as Tobin's $q$ ) and debt renegotiability.

The presence of the investment option may result in a higher total face value of debt, $b^{*} / r$, at the optimal leverage level. Still, the increment of a face value of debt due to the growth option is generally lower (and at times negative) when debt is renegotiable. Again, the adverse effect of the growth option on the optimal coupon level is the highest when shareholders have substantial bargaining power.

Debt renegotiability and the presence of the growth option affect the firm's debt capacity, defined as the maximum market value of debt the firm is able to issue. Already in the absence of growth options, debt capacity of renegotiable debt is lower than of its non-renegotiable counterpart when equityholders' bargaining power is considerable (cf. $\eta=0.75$ in our basic case). Debt capacity of renegotiable debt also increases with creditors' bargaining power. These two results (see Table 4) are consistent with Fan and Sundaresan (2000). The growth option results in a higher debt capacity since it is associated with a higher opportunity cost of default (due to foregoing the growth option upon default). The presence of the growth option improves debt capacity irrespective of the debt restructuring procedure employed and of the distribution of bargaining power. However, the incremental debt capacity of the growth option is generally limited when debt is renegotiable. Again, such a reduced incremental debt capacity is most apparent when equityholders' bargaining power $\eta$ is high. In contrast, renegotiable debt combined with high creditors' ability to manage the firm, $\rho$, and low equityholders' bargaining power has a higher (incremental) capacity than nonrenegotiable debt.

\subsection{Type of Debt and the Value of the Firm}

We conclude the discussion of numerical results with the analysis of the optimal choice of the type of debt. In the existing literature, the choice between non-renegotiable and renegotiable (or, public and private) debt is explained by, among others, flotation costs, monitoring 
incentives of the lender (Diamond (1984)), borrower's reputation building (Diamond (1991)), the efficiency of a liquidation procedure (Berlin and Loeys (1988)) and managerial incentives (Rajan (1992)). In our framework, renegotiable debt allows, on the one hand, for avoiding bankruptcy costs and premature liquidation. On the other hand, it not only leads to an earlier (strategic) default (cf. Mella-Barral and Perraudin (1997) but is also associated with additional underinvestment.

The optimal choice of the type of debt is made by comparing the value of the firm at its optimal capital structure for both types of debt. We calculate the value of the firm for an array of parameter values such that for each entry up to 2 parameter values differ from the basic case (see Table 5). In such a way, we are able to detect the effect of potential interactions between any two parameters on the optimal choice of debt.

[Please insert Table 5 about here.]

For the basic set of parameter values, renegotiable debt allows for increasing the value of the firm by $2.52 \%$. In particular, the advantage of renegotiable debt can be observed when bargaining power of equityholders is relatively low $(\eta=0.25)$. In this case, debt renegotiability adds $7.58 \%$ to the firm value. With low equityholders' bargaining power, the benefit of renegotiable debt increases with the effective tax rate and is substantially eroded when cash flow volatility is low. The latter result follows from the fact that lower $\sigma$ makes default considerations less relevant. Perhaps a bit surprisingly, higher bankruptcy costs generally reduce the advantage of renegotiable debt. For example, for $\rho=0.25$ and the remaining parameter values as in the basic scenario, the advantage of renegotiable debt falls to $0.85 \%$. This result is caused by the positive relation between these costs and the strategic default threshold. Although renegotiation allows for avoiding costly bankruptcy, it triggers an earlier default, which adversely affects the present value of tax shield as well as the efficiency of the investment policy. In fact, in the presence of high interest rates, a high return shortfall or a low profit volatility, non-renegotiable debt is optimal when bankruptcy costs are high (for $\rho=0.25$, debt renegotiability reduces the firm value by up to $5.54 \%$ ). Furthermore, upon analyzing the last column of Table 5 we conclude that high tax rate almost uniformly favors non-renegotiable debt. The intuition is similar to that in the case of high bankruptcy costs - an earlier strategic default generally reduces the present value of the tax shield to a greater extent than a more remote bankruptcy. (In both cases, the conclusion is opposite if equityholders' bargaining power $\eta$ is low.)

The effect of the growth option on the type of debt can be analyzed by comparing the optimal choices in the basic case with those made when growth option is more in-the-money (low $I$ and high $x_{0}$ ). For all but one combinations of parameter values, a more in-the-money growth option is associated with a lower advantage (or a higher disadvantage) of renegotiable debt. For example, a US $\$ 10$ million cut in the investment cost to $\$ 39.98$ million reduces the benefit of renegotiable debt from $2.52 \%$ to $1.56 \%$ of the firm value. Finally, non-renegotiable debt is generally optimal when cash flow volatility is low $(\sigma=0.1)$. This result can be attributed to a lower probability of default and a higher importance of the efficiency of the investment policy. 


\section{Empirical implications}

The paper provides a number of testable empirical implications. Implications 1-3 follow from the results of the model obtained in Section 2, whereas implications 4 and 5 are based on the numerical results of Section 3. In all of the hypotheses, debt renegotiability can be proxied by the ratio of private debt and total debt (Asquith and Scharfstein (1994), and Franks and Torous (1994)), the concentration of equityholders and creditors (Davydenko and Strebulaev (2007)), and the inverse of the index of creditors' power to enforce their claims (Favara et al. (2009)). Moreover, the hypothesized empirical relationships are expected to be stronger when equityholders' bargaining power, $\eta$, is higher and the efficiency of creditors as managers of the firm's assets, $\rho$, is lower. Equityholders' bargaining power can be proxied by the fraction of equity held by the CEO (Davydenko and Strebulaev (2007)), the firm's asset size, and the inverse of the ratio of the R\&D expenses to total assets (Garlappi et al. (2008)). The value of the assets when held by creditors, captured by $\rho$, is assumed to increase in asset tangibility and to decrease in the industry concentration (Garlappi et al. (2008)).

1) The coefficient of the interaction term of debt renegotiability with the debt overhang proxy (cf. Hennessy et al. (2007)) is expected to have a negative sign in an investment regression.

The basic investment model based on $q$-theory can be extended for the effect of debt financing by including a proxy for debt overhang (as in Hennessy et al. (2007)). This proxy takes into account, among others, the leverage ratio, the expected recovery rate based on the SIC code of the industry in which the firm operates as well as the estimate of the default probability based on the debt rating (or the firm's Z-score if the rating is not available). In our model, debt renegotiability results ceteris paribus in an excessively delayed investment, or more severe underinvestment. Therefore, it is expected that the firms that are financed with renegotiable debt will have their coefficient of the debt overhang proxy lower (higher in the absolute terms) than firms financed with non-renegotiable debt. As a consequence, in a regression model run jointly for both types of firms, the coefficient of the interaction term of debt renegotiability with the debt overhang proxy is expected to have a negative sign.

2) The positive effect of growth opportunities on the systematic risk of the firm's equity will be muted if the firm is financed with renegotiable debt.

Carlson et al. (2004) show that the presence of investment opportunities increases the systematic risk of the firm's equity as their beta is greater than that of the firm's assets in place. In the same way, the presence of default option reduces the systematic risk since the possibility of exit acts as insurance against adverse cash flow shocks. Favara et al. (2009) expand on the later point and show that the systematic risk of equity is lower if the expected payoff to equityholders upon (strategic) default is greater. According to our model, debt renegotiability will mitigate the positive effect of growth options as their exercise is expected to be excessively delayed. Empirically, we expect the coefficient of the interaction term of 
the Tobin's $q$ and debt renegotiability to be negative in a regression model of the systematic risk of equity. ${ }^{33}$

3) The presence of the renegotiation option combined with high shareholders' bargaining power is expected to reduce the sensitivity of investment to the firm's cash flow.

In the framework applied in this paper, investment is triggered by a sufficiently high level of cash flow from operations. This implies that a higher magnitude of Myers (1977) underinvestment makes investment less likely to be triggered by an incremental cash flow increase for any initial cash flow level. As a consequence, the presence of the renegotiation option combined with high shareholders' bargaining power, which results in higher underinvestment, is likely to reduce the sensitivity of investment to the firm's cash flow. Therefore, the model provides an alternative explanation of the empirical evidence that small and young firms (as well as companies financed with public debt), exhibit relatively higher investment-cash flow sensitivity (see Hubbard (1998), Boyle and Guthrie (2003), and Lyandres (2007)). ${ }^{34}$

4) An increase in the investment opportunity set of a firm generally leads to a bigger reduction in the credit spread of its debt when renegotiation frictions are smaller.

The riskiness of debt reflected by its credit spread is highly influenced by the presence of both an investment and a renegotiation option. Mella-Barral and Perraudin (1997) show that allowing for the possibility of strategic debt service can significantly increase spreads, as the effect of the anticipated concessions made to equityholders can dominate the benefits of avoiding the bankruptcy costs. The results of our model paper imply that the presence of investment opportunities leads to a bigger reduction in a credit spread of renegotiable debt, unless equityholders' bargaining power is exceptionally high (the effect of bargaining power distribution is therefore expected to be non-monotonic, see Proposition 5) and the distance to default is small.

5) The coefficient of the interaction term of debt renegotiability with Tobin's $q$ is expected to have a negative sign in the leverage regression.

Finally, our model yields a testable prediction for the optimal capital structure decisions. In Section 3 we obtain that the presence of the growth option reduces the optimal leverage by a larger magnitude if debt is renegotiable. Therefore, for such debt the negative effect of growth options on the optimal leverage (cf. Barclay et al. (2006)) will be exacerbated. Empirically, we expect the coefficient of the interaction term of debt renegotiation with Tobin's $q$ to have a negative sign in the leverage regression.

\footnotetext{
${ }^{33}$ To the extent that Tobin's $q$ can already reflect the anticipated additional delay in investment resulting from renegotiable debt financing, one may want to instrument it by a (set of) variable(s) that are correlated with the investment opportunity set and unrelated to the (perceived) efficiency of the firm's investment policy.

${ }^{34}$ Obviously, in our model cash flow is positively related to the value of the investment opportunity. Still, as Tobin's $q$ is generally not a sufficient statistic for the former (as the relation between the two depends on other characteristics of a firm), both variables can be meaningfully used in the investment regression.
} 


\section{Conclusions}

It is known that the investment policy of a firm is affected by its capital structure. The presence of risky debt financing results in an inefficient delay in exercising corporate growth options. We show that the possibility of debt renegotiation at the times of financial distress exacerbates the underinvestment problem upon the firm's expansion. This is a consequence of the fact that the wealth transfer from equityholders to creditors which occurs upon investment is larger when the renegotiation option is present. The additional inefficiency in the investment policy is more severe when equityholders have a stronger bargaining position and the bankruptcy costs are high, and it can be eliminated by granting the entire bargaining power to creditors. This result highlights the importance of the type of debt financing and of the degree of enforcement of creditors' rights on the way corporate investment decisions are made.

Debt restructuring policy itself is affected by the presence of the growth option. In most scenarios, the growth option reduces the probability of strategic default due to a higher opportunity cost of doing so. However, the presence of the growth opportunity can accelerate renegotiation if shareholders' bargaining power is sufficiently high. In the opposite situation, that is, when creditors hold substantial bargaining power, renegotiation occurs later. Finally, the paper provides a number of empirical implications concerning the effect of the type of debt on, among others, investment, equity systematic risk and the capital structure policy.

\section{A. Appendix}

Proof of Proposition 1. An arbitrary claim, $F(x)$, contingent on $x$, and yielding instantaneous cash flow $B x+C$, where $B, C \in \mathbb{R}$, satisfies the ordinary differential equation (ODE)

$$
r F(x)=(r-\delta) x \frac{\partial F(x)}{\partial x}+\frac{1}{2} \sigma^{2} x^{2} \frac{\partial^{2} F(x)}{\partial x^{2}}+B x+C .
$$

Consequently, the value of the firm, $V_{i}(x)$, its equity, $E_{i}(x)$, debt, $D_{i}(x)$, and the value of the firm in the hands of the creditors, $R_{i}(x)$, all satisfy ODE (A.1). Constants $B$ and $C$ are equal, respectively, to $\theta^{i}(1-\tau)$ and $b \tau$ for the firm, to $\theta^{i}(1-\tau)$ and $-b(1-\tau)$ for the equity, to 0 and $b$ for the debt, and to $\rho \theta^{i}(1-\tau)$ and 0 for the firm when run by the creditors. The solution to (A.1) is of the form

$$
F(x)=\frac{B}{\delta}+\frac{C}{r}+M_{1} x^{\beta_{1}}+M_{2} x^{\beta_{2}} .
$$

Constants $M_{1}$ and $M_{2}$ are determined from boundary conditions specific to each claim. ${ }^{35}$

The value of equity can therefore be expressed as

$$
E_{1}(x)=\frac{\theta x(1-\tau)}{\delta}-\frac{b(1-\tau)}{r}+B_{1} x^{\beta_{2}}
$$

\footnotetext{
${ }^{35}$ After investment, $M_{2}=0$ since there is no upper action trigger.
} 
where $B_{1} x^{\beta_{2}}$ is the value of the debt restructuring option. $B_{1}$ and $\underline{x}_{r_{1}}$ are obtained from the following value-matching and smooth-pasting conditions:

$$
\begin{aligned}
\frac{\theta x(1-\tau)}{\delta}-\frac{b(1-\tau)}{r}+B_{1} \underline{x}_{r_{1}}^{\beta_{2}} & =\eta\left[V_{1}\left(\underline{x}_{r_{1}}\right)-R_{1}\left(\underline{x}_{r_{1}}\right)\right], \\
\frac{\theta(1-\tau)}{\delta}+\beta_{2} B_{1} \underline{x}_{r_{1}}^{\beta_{2}-1} & =\left.\eta \frac{\partial\left[V_{1}(x)-R_{1}(x)\right]}{\partial x}\right|_{x=\underline{x}_{r_{1}}} .
\end{aligned}
$$

This gives

$$
B_{1}=\left[\eta\left(V_{1}\left(\underline{x}_{r_{1}}\right)-R_{1}\left(\underline{x}_{r_{1}}\right)\right)+\frac{b(1-\tau)}{r}-\frac{\theta \underline{x}_{r_{1}}(1-\tau)}{\delta}\right] \underline{x}_{r_{1}}^{-\beta_{2}},
$$

and $\underline{x}_{r_{1}}$ is obtained by multiplying both sides of condition (A.4) by $\beta_{2} \underline{x}_{r_{1}}^{-1}$ and subtracting it from (A.5).

The value of the tax shield, $T S_{i}(x)$, satisfies ODE (A.1), so its value can be expressed as

$$
T S_{i}(x)= \begin{cases}N_{1} x^{\beta_{1}}+N_{2} x^{\beta_{2}} & x<\underline{x}_{r_{i}} \\ \frac{b \tau}{r}+N_{3} x^{\beta_{1}}+N_{4} x^{\beta_{2}} . & x \geq \underline{x}_{r_{i}} .\end{cases}
$$

Since

$$
\begin{aligned}
& \lim _{x \uparrow \infty} T S_{i}(x)=\frac{b \tau}{r}, \text { and } \\
& \lim _{x \downarrow 0} T S_{i}(x)=0
\end{aligned}
$$

it holds that $N_{2}=N_{3}=0$. The only remaining unknown constants are $N_{1}$ and $N_{4}$. Now, one needs to consider two cases. If renegotiation is not allowed $(k=0), N_{1}=0$ as the tax shield is irreversibly lost upon default. Then, $N_{4}$ is calculated by applying the value-matching condition

$$
\lim _{x \uparrow \underline{x}_{r_{i}}} T S_{i}(x)=\lim _{x \downarrow \underline{x}_{r_{i}}} T S_{i}(x),
$$

which gives

$$
N_{4}=-\frac{b \tau}{r} \underline{x}_{r_{i}}^{-\beta_{2}} .
$$

If renegotiation is allowed for $(k=1)$, there is no restriction on $N_{1}$, and it is determined simultaneously with $N_{4}$ using value-matching condition (A.10) and the following smoothpasting condition ${ }^{36}$

$$
\left.\frac{\partial T S_{i}(x)}{\partial x}\right|_{x \uparrow \underline{x}_{r_{i}}}=\left.\frac{\partial T S_{i}(x)}{\partial x}\right|_{x \downarrow \underline{x}_{r_{i}}} .
$$

\footnotetext{
${ }^{36}$ The smooth-pasting condition reflects the fact that renegotiation trigger $\underline{x}_{r_{i}}$ is a reversible switch point and does entail any optimization. Continuity of the first derivative of the value function at $\underline{x}_{r_{i}}$ is then required for no arbitrage (for details see Dumas (1991)).
} 
This results in

$$
\begin{aligned}
& N_{1}=\frac{b \tau}{r} \frac{-\beta_{2}}{\beta_{1}-\beta_{2}} \underline{x}_{r_{i}}^{-\beta_{1}}, \text { and } \\
& N_{4}=\frac{b \tau}{r} \frac{-\beta_{1}}{\beta_{1}-\beta_{2}} \underline{x}_{r_{i}}^{-\beta_{2}} .
\end{aligned}
$$

The optimal liquidation trigger can be found by applying the following value-matching and smooth-pasting conditions to the value of the firm:

$$
\begin{aligned}
\frac{\underline{x}_{l_{1}} \theta(1-\tau)}{\delta}+T S_{1}\left(\underline{x}_{l_{1}}\right)+(k-1) B C_{1}\left(\underline{x}_{l_{1}}\right)+L_{1} \underline{x}_{l_{1}}^{\beta_{2}} & =\gamma_{1} \\
\frac{\theta(1-\tau)}{\delta}+\frac{\beta_{1}}{\underline{x}_{l_{1}}} T S_{1}\left(\underline{x}_{l_{1}}\right)+\left.(k-1) \frac{\partial B C_{1}(x)}{\partial x}\right|_{x=\underline{x}_{l_{1}}}+\beta_{2} L_{1} \underline{x}_{l_{1}}^{\beta_{2}-1}= & 0 .
\end{aligned}
$$

Constant $L_{1}$ can be directly calculated from (A.15). Multiplying both sides of condition (A.15) by $\beta_{2} \underline{x}_{l_{1}}^{-1}$ and subtracting it from (A.16) yields the implicit formula for $\underline{x}_{l_{1}}$. Obviously, if debt restructuring has the form of bankruptcy, it is creditors who ultimately shut down the firm.

Proof of Proposition 2. The value of the firm's securities and the level of optimal action triggers can be bound by solving ODE (A.1) for the firm and its equity subject to the following value-matching and smooth-pasting conditions:

$$
\begin{aligned}
V_{0}(\bar{x}) & =V_{1}(\bar{x})-I, \\
E_{0}(\bar{x}) & =E_{1}(\bar{x})-I, \\
\left.\frac{\partial E_{0}(x)}{\partial x}\right|_{x=\bar{x}} & =\left.\frac{\partial E_{1}(x)}{\partial x}\right|_{x=\bar{x}}, \\
E_{0}\left(\underline{x}_{r_{0}}\right) & =\eta\left[V_{0}\left(\underline{x}_{r_{0}}\right)-R_{0}\left(\underline{x}_{r_{0}}\right)\right], \\
\left.\frac{\partial E_{0}(x)}{\partial x}\right|_{x=\underline{x}_{r_{0}}} & =\left.\eta \frac{\partial\left[V_{0}(x)-R_{0}(x)\right]}{\partial x}\right|_{x=\underline{x}_{0}}, \\
V_{0}\left(\underline{x}_{l_{0}}\right) & =\gamma_{0}, \\
\left.\frac{\partial V_{0}(x)}{\partial x}\right|_{x=\underline{x}_{l_{0}}} & =0 .
\end{aligned}
$$

Define matrix $\Theta(\bar{x}, \underline{x})$ as

$$
\Theta(\bar{x}, \underline{x}) \equiv \frac{1}{\bar{x}^{\beta_{1}} \underline{x}^{\beta_{2}}-\underline{x}^{\beta_{1}} \bar{x}^{\beta_{2}}}\left[\begin{array}{rr}
\underline{x}^{\beta_{2}} & -\bar{x}^{\beta_{2}} \\
-\underline{x}^{\beta_{1}} & \bar{x}^{\beta_{1}}
\end{array}\right]
$$

For $k=1$, constants $G_{v}^{(1)}$ and $L_{0}^{(1)}$ reflecting the growth opportunity and the liquidation 
option, respectively, are calculated from conditions (A.17) and (A.22):

$$
\begin{aligned}
{\left[\begin{array}{c}
G_{v}^{(1)} \\
L_{0}^{(1)}
\end{array}\right] } & =\Theta\left(\bar{x}, \underline{x}_{l_{0}}\right)\left[\begin{array}{l}
\frac{(\theta-1) \bar{x}(1-\tau)}{\delta}+T S_{1}(\bar{x})-T S_{0}(\bar{x})-I+L_{1} \bar{x}^{\beta_{2}} \\
\gamma_{0}-\frac{\underline{x}_{l_{0}}(1-\tau)}{\delta}-T S\left(\underline{x}_{l_{0}}\right)
\end{array}\right] \\
& \equiv \Theta\left(\bar{x}, \underline{x}_{l_{0}}\right)\left[\begin{array}{l}
\Pi_{u}(\bar{x}) \\
\Pi_{d}\left(\underline{x}_{r_{0}}\right)
\end{array}\right] .
\end{aligned}
$$

The sum of both option values, $G_{v}^{(1)} x^{\beta_{1}}+L_{0}^{(1)} 1 x^{\beta_{2}}$, can be expressed as

$$
\Pi_{u}(\bar{x}) \bar{\Lambda}\left(\bar{x}, \underline{x}_{r_{0}} ; x\right)+\Pi_{d}\left(\underline{x}_{r_{0}}\right) \underline{\Lambda}\left(\underline{x}_{r_{0}}, \bar{x} ; x\right),
$$

where

$$
\begin{aligned}
& \bar{\Lambda}(\bar{x}, \underline{x} ; x) \equiv \mathbb{E}\left[e^{-r T_{\bar{x}}} \mathbf{1}_{\left\{T_{\bar{x}}<T_{\underline{x}}\right\}} \mid x\right]=\frac{x^{\beta_{1}} \underline{x}^{\beta_{2}}-\underline{x}^{\beta_{1}} x^{\beta_{2}}}{\bar{x}^{\beta_{1}} \underline{x}^{\beta_{2}}-\underline{x}^{\beta_{1}} \bar{x}^{\beta_{2}}}, \\
& \underline{\Lambda}(\underline{x}, \bar{x} ; x) \equiv \mathbb{E}\left[e^{-r T_{\underline{x}}} \mathbf{1}_{\left\{T_{\underline{x}}<T_{\bar{x}}\right\}} \mid x\right]=\frac{\bar{x}^{\beta_{1}} x^{\beta_{2}}-x^{\beta_{1}} \bar{x}^{\beta_{2}}}{\bar{x}^{\beta_{1}} \underline{x}^{\beta_{2}}-\underline{x}^{\beta_{1}} \bar{x}^{\beta_{2}}},
\end{aligned}
$$

and $T_{y}$ is the stopping time at realization $y$ of process $(1)$. Consequently, $\bar{\Lambda}(\bar{x}, \underline{x} ; x)(\underline{\Lambda}(\underline{x}, \bar{x} ; x))$ is the present value of $\$ 1$ received upon process $x$ hitting upper barrier $\bar{x}$ (lower barrier $\underline{x}$ ) conditional on not hitting $\underline{x}(\bar{x})$ before and starting from level $x$ (see Geman and Yor (1996)). The expressions in square brackets in (A.26) are net payoffs associated with hitting the corresponding thresholds.

For $k=0$, the value of the growth option is calculated using the fact that investment opportunity is lost upon bankruptcy at $\underline{x}_{r_{0}}^{(0)}$. Therefore, this value for $x \geq \underline{x}_{r_{0}}^{(0)}$ can be decomposed as $G_{v}^{(0)} x^{\beta_{1}}+G_{v}^{-} x^{\beta_{2}}$, where:

$$
\begin{aligned}
& {\left[\begin{array}{l}
G_{v}^{(0)} \\
G_{v}^{-}
\end{array}\right]=\Theta\left(\bar{x}, \underline{x}_{r_{0}}^{(0)}\right) \times} \\
& {\left[\begin{array}{l}
\left.\frac{(\theta-1) \bar{x}(1-\tau)}{\delta}+T S_{1}(\bar{x})-T S_{0}(\bar{x})-B C_{1}(\bar{x})+B C_{0}(\bar{x})-I+L_{1} \bar{x}^{\beta_{2}}\right] \\
0
\end{array}\right]}
\end{aligned}
$$

and (A.29) is obtained by solving value-matching condition (A.17) with an auxiliary valuematching condition ensuring the continuity of the firm value at $\underline{x}_{r_{0}}^{(0)}$. Now, the following simplification can be made:

$$
G_{v}^{(0)} x^{\beta_{1}}+G_{v}^{-} x^{\beta_{2}}=G_{v}^{(0)} x^{\beta_{1}}\left[1-\left(\frac{x}{\underline{x}_{r_{0}}^{(0)}}\right)^{\beta_{2}-\beta_{1}}\right] .
$$

Constant $L_{(0)}^{0}$ is calculated analogously as in (A.15) as there is no growth option after bankruptcy. 
Finally, constants $G$ and $B_{0}$ reflecting the equityholders' value of the growth and debt restructuring options, respectively, are calculated from (A.18) and (A.20): ${ }^{37}$

$$
\begin{aligned}
& {\left[\begin{array}{c}
G_{0} \\
B_{0}
\end{array}\right]=\Theta\left(\bar{x}, \underline{x}_{r_{0}}\right) \times} \\
& {\left[\begin{array}{l}
\frac{(\theta-1) \bar{x}(1-\tau)}{\delta}+\left(\eta\left(V_{1}\left(\underline{x}_{r_{1}}\right)-R_{1}\left(\underline{x}_{r_{1}}\right)\right)-\frac{\theta \underline{x}_{r_{1}}(1-\tau)}{\delta}+\frac{b(1-\tau)}{r}\right)\left(\frac{\bar{x}}{\underline{x}_{r_{1}}}\right)^{\beta_{2}}-I \\
\eta\left(V_{0}\left(\underline{x}_{r_{0}}\right)-R_{0}\left(\underline{x}_{r_{0}}\right)\right)\left(\frac{\bar{x}}{\underline{x}_{r_{0}}}\right)^{\beta_{2}}-\frac{\underline{x}_{r_{0}}(1-\tau)}{\delta}+\frac{b(1-\tau)}{r}
\end{array}\right] .}
\end{aligned}
$$

The implicit formulae for the optimal investment threshold, $\bar{x}$, optimal debt restructuring trigger, $\underline{x}_{r_{0}}$, and liquidation trigger, $\underline{x}_{l_{0}}$, are obtained by pairwise rearranging equations (A.18)-(A.19), (A.20)-(A.21), and (A.22)-(A.23).

Proof of Proposition 3. Underinvestment occurs as long as $B_{0}>B_{1}$, since in this case the optimal investment threshold, $\bar{x}$, is higher than a corresponding threshold of an otherwise identical all-equity firm. ${ }^{38}$ To show that in fact $B_{0}>B_{1}$, both constants are expressed as follows:

$$
\begin{aligned}
B_{0}= & {\left[\frac{b}{r}-\frac{(1-\eta(1-\rho)) \underline{x}_{r_{0}}}{\delta}\right.} \\
& \left.-\left((1-\eta)\left(\frac{(\theta-1) \bar{x}}{\delta}-I\right)+\left(B_{1}-B_{0}\right) \bar{x}^{\beta_{2}}\right)\left(\frac{\underline{x}_{r_{0}}}{\bar{x}}\right)^{\beta_{1}}\right] \underline{x}_{r_{0}}^{-\beta_{2},} \\
B_{1}= & \left(\frac{b}{r}-\frac{\theta(1-\eta(1-\rho)) \underline{x}_{r_{1}}}{\delta}\right) \underline{x}_{r_{1}}^{-\beta_{2}} .
\end{aligned}
$$

(A.32) is obtained by combining (A.6) and (A.31). (A.33) is obtained from (A.6). Now, define function $B_{0}(\cdot)$ so that the value of option to go bankrupt at an exogenously given trigger $y$ is $B_{0}(y) x^{\beta_{2}}$ (of course, it must hold that $B_{0}\left(\underline{x}_{r_{0}}\right) x^{\beta_{2}}=B_{0} x^{\beta_{2}}$ ). Then, the difference $B_{0}\left(\underline{x}_{r_{1}}\right)-B_{1}$ can be expressed as

$$
\begin{aligned}
B_{0}\left(\underline{x}_{r_{1}}\right)-B_{1}= & \underline{x}_{r_{1}}^{-\beta_{2}}\left[\frac{(\theta-1)(1-\eta(1-\rho)) \underline{x}_{r_{1}}}{\delta}\right. \\
& \left.-\left((1-\eta)\left(\frac{(\theta-1) \bar{x}}{\delta}-I\right)+\left(B_{1}-B_{0}\left(\underline{x}_{r_{1}}\right)\right) \bar{x}^{\beta_{2}}\right)\left(\frac{\underline{x}_{r_{1}}}{\bar{x}}\right)^{\beta_{1}}\right],
\end{aligned}
$$

which is equivalent to

$$
\begin{aligned}
B_{0}\left(\underline{x}_{r_{1}}\right)-B_{1}= & \left(1-\left(\frac{\underline{x}_{r_{1}}}{\bar{x}}\right)^{\beta_{1}-\beta_{2}}\right)^{-1}\left[\frac{(\theta-1)(1-\eta) \underline{x}_{r_{1}}}{\delta}\left(1-\left(\frac{\underline{x}_{r_{1}}}{\bar{x}}\right)^{\beta_{1}-1}\right)\right. \\
& \left.+\frac{(\theta-1) \eta \rho \underline{x}_{r_{1}}}{\delta}+I(1-\eta)\left(\frac{\underline{x}_{r_{1}}}{\bar{x}}\right)^{\beta_{1}}\right] \underline{x}_{r_{1}}^{-\beta_{2}}
\end{aligned}
$$

\footnotetext{
${ }^{37}$ The option-like components of equity can also be expressed along the lines of (A.26).

${ }^{38}$ Proofs of Propositions 3 and 4 are presented for $\gamma_{i}=\tau=0, i \in\{0,1\}$. Extensive numerical simulations in the parameter space $\left\{\left(\delta, \sigma, r, \eta, \rho, I, \tau, \theta, \gamma_{0}, \gamma_{1}, b\right) \in \mathbb{R}^{11} \mid \delta>0, \sigma>0, r>0,0 \leq \eta \leq 1,0 \leq \rho<1, I>\right.$ $\left.0,0 \leq \tau<1, \theta>1, \gamma_{0}>0, \gamma_{1}>0, b \geq 0\right\}$ indicate that the results of both propositions hold also for strictly positive levels of the tax rate and liquidation values.
} 
Expression (A.35) is positive as all its components are positive. This implies that even the value of the suboptimally exercised option $B_{0}\left(\underline{x}_{r_{1}}\right) x^{\beta_{2}}$ is higher than the value of the option $B_{1} x^{\beta_{2}}$. This implies that the value of the restructuring option $B_{0} x^{\beta_{2}}$, which is at least as high as $B_{0}\left(\underline{x}_{r_{1}}\right) x^{\beta_{2}}$, exceeds $B_{1} x^{\beta_{2}}$ as well.

Proof of Proposition 4. Recall that the optimal investment threshold, $\bar{x}$ (cf. (6)), is given by

$$
\bar{x}=\frac{\beta_{1}}{\beta_{1}-1} \frac{\delta I}{\theta-1}+\frac{\beta_{1}-\beta_{2}}{\beta_{1}-1} \frac{\delta\left(B_{0}^{(k)}-B_{1}^{(k)}\right) \bar{x}^{\beta_{2}}}{\theta-1} .
$$

To evaluate the difference in investment thresholds, we proceed in the following steps. First, we show that the difference $B_{0}^{(k)}-B_{1}^{(k)}$ is larger for renegotiable debt $(k=1)$ if shareholders can make take-it or leave-it offers $(\eta=1)$. Then, we use the fact that no difference occurs when creditors hold the entire bargaining power $(\eta=0)$. (Recall that $B_{i}^{(0)}=B_{i}^{(1)}, i \in\{0,1\}$, for $\eta=0$, cf. (A.6) and (A.31).) Finally, we show that $B_{0}^{(1)}-B_{1}^{(1)}$ increases with bargaining power parameter $\eta$.

Consider first the value of an option to restructure debt in the absence of the investment option, $\hat{B}_{i}^{(k)} x^{\beta_{2}}$. (Obviously, $\hat{B}_{1}^{(k)}=B_{1}^{(k)}$.) After substituting (7) for $\underline{x}_{r_{1}}$ in (A.33) and observing that $\hat{B}_{0}^{(k)} x^{\beta_{2}}$ is obtained analogously, it follows that

$$
\hat{B}_{i}^{(k)} x^{\beta_{2}}=\frac{\left(1-\beta_{2}\right)^{\beta_{2}-1}}{\beta_{2}^{\beta_{2}}} \frac{r^{\beta_{2}-1}\left(\rho^{k} \theta^{i} x\right)^{\beta_{2}}}{b^{\beta_{2}-1} \delta^{\beta_{2}}} \equiv K\left(\rho^{k} \theta^{i} x\right)^{\beta_{2}},
$$

With renegotiation, the relevant difference $\hat{B}_{0}^{(1)}-B_{1}^{(1)}$ equals $K[\rho(1-\theta) x]^{\beta_{2}}$, which is larger than the analogous difference for non-renegotiable debt, $K[(1-\theta) x]^{\beta_{2}}$ ( $\beta_{2}$ is negative). Therefore, when the effect of the growth option is disregarded, the difference in the option values to restructure debt for the original and the expanded firm is larger when debt is renegotiable.

Now, observe that $B_{0}^{(0)} x^{\beta_{2}}$, i.e., the option to go bankrupt, must be worth less than (A.37) evaluated for $k=i=0$, as the expansion option increases the opportunity cost of bankruptcy (cf. (A.32)). In other words, $B_{0}^{0} x^{\beta_{2}}$ is always more out of the money (or less in the money) than $\hat{B}_{0}^{(0)} x^{\beta_{2}}$. Therefore, $B_{0}^{(0)}-B_{1}^{(0)}<\hat{B}_{0}^{(0)}-B_{1}^{(0)}=K x^{\beta_{2}}\left(1-\theta^{\beta_{2}}\right)$.

Now, we show that for $\eta=1, B_{0}^{(1)}-B_{1}^{(1)}>\hat{B}_{0}^{(1)}-B_{1}^{(1)}=K(\rho x)^{\beta_{2}}\left(1-\theta^{\beta_{2}}\right)$. Again, let function $B_{0}(y) x^{\beta_{2}}$ be the value of the debt restructuring option exercised (possibly not optimally) at an exogenously given trigger $y$. The renegotiation option, $B_{0}^{(1)}(y) x^{\beta_{2}}$, for $\eta=1$ is then given by

$$
B_{0}^{(1)}(y) x^{\beta_{2}}=\left[\frac{b(1-\tau)}{r}-\frac{\rho y(1-\tau)}{\delta}+\left(B_{0}^{(1)}(y)-B_{1}^{(1)}\right) \bar{x}^{\beta_{2}}\left(\frac{y}{\bar{x}}\right)^{\beta_{1}}\right]\left(\frac{x}{y}\right)^{\beta_{2}} .
$$

After substituting $\theta \underline{x}_{r_{1}}$ for $y,($ A.38) can be expressed as

$$
B_{0}^{(1)}\left(\theta \underline{x}_{r_{1}}\right) x^{\beta_{2}}=\hat{B}_{0}^{(1)} x^{\beta_{2}}+\left(B_{0}^{(1)}\left(\theta \underline{x}_{r_{1}}\right)-B_{1}^{(1)}\right) x^{\beta_{2}}\left(\frac{\theta \underline{x}_{r_{1}}}{\bar{x}}\right)^{\beta_{1}-\beta_{2}} .
$$


Furthermore, by subtracting the product of (A.33) and $x^{\beta_{2}}$ from (A.38) (with $y=\theta \underline{x}_{r_{1}}$ ), one obtains that $B_{0}^{(1)}\left(\theta \underline{x}_{r_{1}}\right)>B_{1}^{(1)}$. This inequality is equivalent to $B_{0}^{(1)}\left(\theta \underline{x}_{r_{1}}\right)>\hat{B}_{0}^{(1)}$. In turn, the latter implies that $B_{0}^{(1)}>\hat{B}_{0}^{(1)}$, as $B_{0}^{(1)}$ is a constant corresponding to the option with an unconstrained exercise policy and, and such, cannot be smaller than $B_{0}^{(1)}\left(\theta \underline{x}_{r_{1}}\right)$. Therefore, referring back to equation (6), the possibility of renegotiation occurring upon default combined with equityholders making take-it or leave-it offers exacerbates underinvestment compared to the situation where bankruptcy occurs upon default.

In fact, the proof of Proposition 4 is also straightforward for all $\eta \geq \eta^{*}$, where $\eta^{*}$ is defined as such a level of the equityholders' bargaining power at which the equality $\eta^{*} G_{v}=G$ is satisfied. First, consider the value of the debt restructuring option that is (suboptimally) exercised at $\theta \underline{x}_{r_{1}}$. It holds that

$$
B_{0}^{(1)}\left(\theta \underline{x}_{r_{1}}\right) x^{\beta_{2}}=\hat{B}_{0}^{(1)} x^{\beta_{2}}+\left(\eta \tilde{G}_{v}-\tilde{G}\right)\left(\theta \underline{x}_{r_{1}}\right)^{\beta_{1}}\left(\frac{x}{\theta \underline{x}_{r_{1}}}\right)^{\beta_{2}},
$$

where $\tilde{G}$ and $\tilde{G}_{v}$ denote the constants corresponding to the equityholders' and the firm's growth options, respectively, with the modified debt restructuring policy (i.e., at $\theta \underline{x}_{r_{1}}$ ). Obviously, $B_{0}^{(1)}\left(\theta \underline{x}_{r_{1}}\right)$ cannot be larger than $B_{0}^{(1)}$ since it is based on a suboptimal exercise policy (In fact, $B_{0}^{(1)}\left(\theta \underline{x}_{r_{1}}\right)=B_{0}^{(1)}$ for $\eta=\eta^{*}$, that is, when $\underline{x}_{r_{0}}=\theta \underline{x}_{r_{1}}$.) Therefore, it is sufficient to show that $\eta \tilde{G}_{v}-\tilde{G}$ is non-negative for $\eta>\eta^{*}$ (which is equivalent to $B_{0}^{(1)}\left(\theta \underline{x}_{r_{1}}\right)>$ $\left.\hat{B}_{0}^{(1)}\right)$. But this is immediate since $\eta \tilde{G}_{v}-\tilde{G}=0$ for $\eta=\eta^{*}$ and is increasing with $\eta$. To see the latter point, notice that for any given expansion policy $\tilde{G}_{v}$ does not depend on $\eta$ and $\tilde{G}$ is decreasing with $\eta$. Again, the latter is due to the fact that trigger $\theta \underline{x}_{r_{1}}$, upon which some value of the equityholders' growth option is lost, increases with $\eta$.

To prove Proposition 4 for $\eta<\eta^{*}$, observe the following. Constant $B_{0}^{(1)}$ of the debt restructuring option can be represented as $a(\eta) \hat{B}_{0}^{(1)}$, where $a(\eta)<1$ for $\eta<\eta^{*}$. To show that $B_{0}^{(1)}-B_{1}^{(1)}$ increases with $\eta$ it is sufficient to show the following: that $a^{\prime}(\eta)>0$ and that $\eta G_{v}-G$ increases with $\eta$. Starting from the latter, the argument is the same as in the previous case: for a given expansion policy, $G_{v}$ remains unchanged and $G$ decreases with $\eta$ due to an increasing trigger $\underline{x}_{r_{0}}$. As the effect of the investment option on the timing of the debt restructuring is reduced $\left(\eta G_{v}-G\right.$ is initially negative), trigger $\underline{x}_{r_{0}}$ moves closer to $\theta \underline{x}_{r_{1}}$. (Recall that the latter trigger corresponds to option $\hat{B}_{0}^{(1)} x^{\beta_{2}}$.) Therefore, the relative disparity between the option constant $B_{0}^{(1)}$ and $\hat{B}_{0}^{(1)}$, captured by the inverse of $a(\eta)$, decreases as well.

Proof of Proposition 5. The proof is straightforward and follows from equation (4). Sice all the remaining factors in the second component of the RHS are positive, $\eta G_{v}-G>0$ implies that $\underline{x}_{r_{0}}$ is higher than the renegotiation threshold in the absence of the expansion option. 


\section{Acknowledgements}

I am grateful to Peter Kort, Thomas Dangl, Avinash Dixit, Ulrich Hege, Bart Lambrecht, Antonio Mello, Łukasz Pomorski, Luc Renneboog, Mark Shackleton, Grzegorz Trojanowski, participants of EEA-ESEM in Madrid, EFA in Glasgow, EFMA in Helsinki, International Conference on Real Options in Washington, seminar participants at CERGE-EI (Prague), Erasmus (Rotterdam), ECARES (Brussels), Lancaster, Norwegian School of Management (BI) and Tilburg, as well as to the anonymous referee for valuable comments and suggestions. All remaining errors are mine.

\section{References}

Acharya, V. V., Carpenter, J. N., 2002. Corporate bond valuation and hedging with stochastic interest rates and endogenous bankruptcy. Review of Financial Studies 15, 1355-1383.

Acharya, V. V., Huang, J., Subrahmanyam, M. G., Sundaram, R. K., 2006. When does strategic debt service matter? Economic Theory 29, 363-378.

Alderson, M. J., Betker, B. L., 1996. Liquidation costs and accounting data. Financial Management 25, $25-36$.

Anderson, R., Sundaresan, S., 1996. Design and valuation of debt contracts. Review of Financial Studies 9, $37-68$.

Asquith, Paul, R. G., Scharfstein, D., 1994. Anatomy of financial distress: An examination of junk bond issuers. Quarterly Journal of Economics 109, 625-658.

Baldursson, F., Karatzas, I., 1997. Irreversible investment and industry equilibrium. Finance and Stochastics 1, 69-89.

Barclay, M. J., Morellec, E., Smith, C. W., 2006. On the debt capacity of growth options. Journal of Business 79, 37-60.

Berlin, M., Loeys, J., 1988. Bond covenants and delegated monitoring. Journal of Finance 43 (2), 397-412.

Bernanke, B. S., Campbell, J. Y., Whited, T. M., 1990. U.S. corporate leverage: Developments in 1987 and 1988. Brookings Papers on Economic Activity 1, 255-278.

Betker, B. L., 1995. Management's incentives, equity bargaining power, and deviations from the absolute priority in Chapter 11 bankruptcies. Journal of Business 68, 161-183.

Bolton, P., Scharfstein, D. S., 1996. Optimal debt structure and the number of creditors. Journal of Political Economy 104, 1-25.

Boyle, G. W., Guthrie, G. A., 2003. Investment, uncertainty, and liquidity. Journal of Finance 58, 2143-2166.

Carlson, M., Fisher, A., Giammarino, R., 2004. Corporate investment and asset price dynamics: Implications for the cross-section of returns. Journal of Finance 59 (6), 2577-2603.

Christensen, P. O., Flor, C. R., Lando, D., Miltersen, K. R., 2002. Dynamic capital structure with callable debt and debt renegotiations, working Paper, University of Southern Denmark.

Dangl, T., Zechner, J., 2004. Credit risk and dynamic capital structure choice. Journal of Financial Intermediation 13, 183-204.

Davydenko, S. A., Franks, J. R., 2008. Do bankruptcy codes matter? a study of defaults in France, Germany, and the U.K. Journal of Finance 63 (2), 565-608.

Davydenko, S. A., Strebulaev, I. A., 2007. Strategic actions and credit spreads: An empirical investigation. Journal of Finance 62 (6), 2633-2671.

Diamond, D. W., 1984. Financial intermediation and delegated monitoring. Review of Economic Studies $51(3), 393-414$.

Diamond, D. W., 1991. Monitoring and reputation: The choice between bank loans and directly placed debt. Journal of Political Economy 99 (4), 689-721.

Dixit, A. K., 1993. The Art of Smooth Pasting. Fundamentals of Pure and Applied Economics, vol. 55. Harwood Academic Publishers. 
Dixit, A. K., Pindyck, R. S., 1994. Investment under Uncertainty. Priceton University Press.

Dumas, B., 1991. Super contact and related optimality conditions. Journal of Economic Dynamics and Control 15, 675-685.

Eckbo, B. E., Thorburn, S. K., 2008. Automatic bankruptcy auctions and fire-sales. Journal of Financial Economics 89 (3), 404-422.

Egami, M., 2009. A framework for the study of expansion options, loan commitments and agency costs. Journal of Corporate Finance 15 (3), 345-357.

Eom, Y. H., Helwege, J., Huang, J.-Z., 2004. Structural models of corporate bond pricing: An empirical analysis. Review of Financial Studies 17 (2), 499-544.

Ericsson, J., 2001. Asset substitution, leverage and maturity. Finance 21.

Fan, H., Sundaresan, S. M., 2000. Debt valuation, renegotiation and optimal dividend policy. Review of Financial Studies 13, 1057-1099.

Favara, G., Schroth, E., Valta, P., 2009. Is shareholders strategic default behavior priced? Evidence from the international cross-section of stock, working paper, University of Lausanne.

Fischer, E. O., Heinkel, R., Zechner, J., 1989. Dynamic capital structure choice: Theory and tests. Journal of Finance 44, 19-40.

François, P., Morellec, E., 2004. Capital structure and asset prices: Some effects of bankruptcy procedures. Journal of Business 77, 387-411.

Franks, J. R., Torous, W. N., 1989. An empirical investigation of U.S. firms in renegotiation. Journal of Finance 44, 747-769.

Franks, J. R., Torous, W. N., 1994. A comparison of financial recontracting in distressed exchanges and Chapter 11 reorganizations. Journal of Financial Economics 35, 349-370.

Garlappi, L., Shu, T., Yan, H., 2008. Default risk, shareholder advantage, and stock returns. Review of Financial Studies 21 (6), 2743-2778.

Geman, H., Yor, M., 1996. Pricing and hedging double-barrier options: A probabilistic approach. Mathematical Finance 4, 365-378.

Graham, J. R., 2000. How big are the tax benefits of debt? Journal of Finance 55 (5), 1901-1941.

Grullon, G., Michaely, R., 2002. Dividends, share repurchases, and the substitution hypothesis. The Journal of Finance 57 (4), 1649-1684.

Hackbarth, D., Hennessy, C. A., Leland, H. E., 2002. Optimal debt mix and priority structure: The role of bargaining power, working Paper, University of California at Berkeley.

Hackbarth, D., Hennessy, C. A., Leland, H. E., 2007. Can the tradeoff theory explain debt structure? Review of Financial Studies (20), 1389-1428.

Hege, U., Mella-Barral, P., 2000. Bargaining power and optimal leverage. Finance 21, 85-101.

Hege, U., Mella-Barral, P., 2005. Repeated dilution of diffusely held debt. Journal of Business 21, 737-786.

Hennessy, C., 2004. Tobin's Q, debt overhang, and investment. Journal of Finance 59, 1717-1742.

Hennessy, C. A., Levy, A., Whited, T. M., 2007. Testing q theory with financing frictions. Journal of Financial Economics 83, 691-717.

Hubbard, R. G., 1998. Capital-market imperfections and investment. Journal of Economic Literature 36, $193-225$.

Leahy, J. V., 1993. Investment in competitive equilibrium: The optimality of myopic behavior. Quarterly Journal of Economics 108, 1105-1133.

Leland, H. E., 1994. Corporate debt value, bond covenants, and optimal capital structure. Journal of Finance 49, 1213-1252.

Leland, H. E., 1998. Agency costs, risk management and capital structure. Journal of Finance 53, $1213-1243$.

LoPucki, L. M., Whitford, W. C., 1990. Bargaining over equity's share in the bankruptcy reorganization of large, publicly held companies. University of Pennsylvania Law Review 139, 129-169.

Lyandres, E., 2007. Costly external financing, investment timing, and investment-cash flow sensitivity. Journal of Corporate Finance 13 (5), 959-980.

Mauer, D. C., Ott, S. H., 2000. Agency costs, underinvestment and optimal capital structure: The effects of growth options to expand. In: Brennan, M. J., Trigeorgis, L. (Eds.), Project Flexibility, Agency, 
and Product Market Competition : New Developments in the Theory and Application of Real Options Analysis. Oxford University Press.

Mauer, D. C., Sarkar, S., 2004. Real options, agency conflicts and optimal capital structure. Journal of Banking and Finance 29, 1405-1428.

Mauer, D. C., Triantis, A. J., 1994. Interactions of corporate financing and investment decisions: a dynamic framework. Journal of Finance 49, 1253-1277.

McDonald, R., Siegel, D., 1986. The value of waiting to invest. Quarterly Journal of Economics 101, 707-728.

Mella-Barral, P., 1999. The dynamics of default and debt reorganization. Review of Financial Studies 12, $535-578$.

Mella-Barral, P., Perraudin, W., 1997. Strategic debt service. Journal of Finance 52, 531-556.

Mello, A. S., Parsons, J. E., 1992. Measuring the agency cost of debt. Journal of Finance 47, 1887-1904.

Morellec, E., 2004. Can managerial discretion explain observed leverage ratios? Review of Financial Studies 17, 257-294.

Morellec, E., Nikolov, B., Schuerhoff, N., 2008. Dynamic capital structure under managerial entrenchment: Evidence from a structural estimation, working Paper, University of Lausanne.

Moyen, N., 2007. How big is the debt overhang problem? Journal of Economic Dynamics and Control 31, 433-472.

Myers, S. C., 1977. Determinants of corporate borrowing. Journal of Financial Economics 5, 147-175.

Parrino, R., Weisbach, M. S., 1999. Measuring investment distortions arising from stockholder-bondholder conflicts. Journal of Financial Economics 53, 3-42.

Rajan, R. G., 1992. Insiders and outsiders: The choice between informed and arm's-length debt. Journal of Finance 47 (4), 1367-1400.

Strebulaev, I. A., 2007. Do tests of capital structure theory mean what they say? Journal of Finance 62, $1747-1787$.

Subramanian, A., 2007. Managerial flexibility, agency costs and optimal capital structure, working paper, Georgia State University.

Sundaresan, S., Wang, N., 2007. Investment under uncertainty with strategic debt service. American Economic Review: Papers and Proceedings 97, 256-261.

Titman, S., Tsyplakov, S., 2007. A dynamic model of optimal capital structure. Review of Finance 11, 401-451.

Vercammen, J., 2000. Irreversible investment under uncertainty and the threat of bankruptcy. Economics Letters $66,319-325$. 


\section{Optimal Investment, Liquidation and Debt Restructuring Policies}

\begin{tabular}{lccccccc}
\hline \hline Threshold & $\begin{array}{c}\text { Coupon } \\
\text { rate }\end{array}$ & $\begin{array}{c}\text { Bargaining } \\
\text { power }\end{array}$ & $\begin{array}{c}\text { Creditors } \\
\text { efficiency }\end{array}$ & Volatility & $\begin{array}{c}\text { Return } \\
\text { shortfall }\end{array}$ & $\begin{array}{c}\text { Interest } \\
\text { rate }\end{array}$ & $\begin{array}{c}\text { Growth } \\
\text { options }\end{array}$ \\
\hline $\bar{x}$ & $b$ & $\eta$ & $\rho$ & $\sigma$ & $\delta$ & $r$ & $I^{-1}, \theta$ \\
$\underline{x}_{r_{0}}^{(1)}$ & $(i)$ & $(i i)$ & $(i i i)$ & + & + & $+/-^{*}$ & - \\
$\underline{x}_{r_{0}}^{(0)}$ & + & + & - & - & + & - & $(i v)$ \\
$\underline{x}_{l_{0}}^{(1)}$ & + & 0 & 0 & - & + & - & - \\
\hline \hline
\end{tabular}

Table 1: Comparative statics concerning the optimal investment, $\bar{x}$, renegotiation, $\underline{x}_{r_{0}}^{(1)}$, bankruptcy, $\underline{x}_{r_{0}}^{(0)}$, and liquidation, $\underline{x}_{l_{0}}^{(1)}$, thresholds. "+", "0", and "-" denote a positive, zero, and negative, respectively, sensitivity with respect to the changes in a given parameter, and " +/ - " indicates an ambiguous sign of the relationship. The numbers in brackets refer to the explanatory notes in the text. ${ }^{* /}$ In the basic investment model, the investment threshold increase with $r$ (when shortfall $\delta$ is held constant), see Dixit and Pindyck (1994). With debt, higher $r$ generally reduces the value of creditors' claim, which can have an accelerating effect on investment (in particular, for low $r$ and $\sigma$ ). 
Valuation of Corporate Claims

\begin{tabular}{lccccccc}
\hline \hline Claim & $\begin{array}{c}\text { Coupon } \\
\text { rate }\end{array}$ & $\begin{array}{c}\text { Bargaining } \\
\text { power }\end{array}$ & $\begin{array}{c}\text { Creditors } \\
\text { efficiency }\end{array}$ & Volatility & $\begin{array}{c}\text { Return } \\
\text { shortfall }\end{array}$ & $\begin{array}{c}\text { Interest } \\
\text { rate }\end{array}$ & $\begin{array}{c}\text { Growth } \\
\text { options }\end{array}$ \\
& $b$ & $\eta$ & $\rho$ & $\sigma$ & $\delta$ & $r$ & $I^{-1}, \theta$ \\
\hline$E_{0}$ & - & + & - & + & - & + & + \\
$D_{0}$ & +- & - & + & $+/-^{*}$ & - & $+/-^{* *}$ & $(v)$ \\
$V_{0}$ & +- & - & + & $+/-$ & - & $+/-$ & + \\
\hline \hline
\end{tabular}

Table 2: Comparative statics concerning the valuation of equity, $E_{0}$, debt, $D_{0}$, and the firm as a whole, $V_{0}$. "+" ("-") denotes a positive (negative) sensitivity with respect to a given parameter, and "+-" ("+/-") indicates a humped (an ambiguous sign of the) relationship. The numbers in brackets refer to the explanatory notes in the text. */ The "junk bond effect" (Leland (1994)) results in a positive relationship between the debt value and cash flow volatility in the neighborhood of the endogenous debt restructuring trigger. ${ }^{* * /}$ The positive effect of a higher risk-neutral drift on the debt value can dominate for low $r$ and $\sigma$. 


\section{Agency Cost of Debt and Debt Overhang}

\begin{tabular}{|c|c|c|c|c|c|c|c|}
\hline Cost & $\begin{array}{c}\text { Coupon } \\
\text { rate } \\
b\end{array}$ & $\begin{array}{c}\text { Bargaining } \\
\text { power } \\
\eta\end{array}$ & $\begin{array}{c}\text { Creditors } \\
\text { efficiency } \\
\rho\end{array}$ & $\begin{array}{c}\text { Volatility } \\
\sigma\end{array}$ & $\begin{array}{c}\text { Return } \\
\text { shortfall } \\
\delta\end{array}$ & $\begin{array}{c}\text { Interest } \\
\text { rate } \\
r\end{array}$ & $\begin{array}{c}\text { Growth } \\
\text { options } \\
I^{-1}, \theta\end{array}$ \\
\hline$A C^{(1)}$ & + & + & - & - & + & - & + \\
\hline$A C^{(0)}$ & + & 0 & - & - & + & - & + \\
\hline$\frac{A C^{(1)}}{A C^{(0)}}$ & $\approx 0$ & + & - & - & - & + & $+/-^{*}$ \\
\hline$I D O$ & + & + & - & - & + & - & + \\
\hline
\end{tabular}

Table 3: Comparative statics concerning the magnitude of the agency cost of renegotiable debt, $A C^{(1)}$, non-renegotiable debt and $A C^{(0)}$, and of incremental debt overhang, IDO. "+", "0" and "-" denote a positive, zero, and negative, respectively, sensitivity with respect to the changes in a given parameter. ${ }^{* /}$ The sign can be negative for $x \ll x^{*}$ when the agency cost of underinvestment is more sensitive to $I$ and $\theta$ for non-renegotiable debt due to a lower investment threshold associated with this type of debt. 


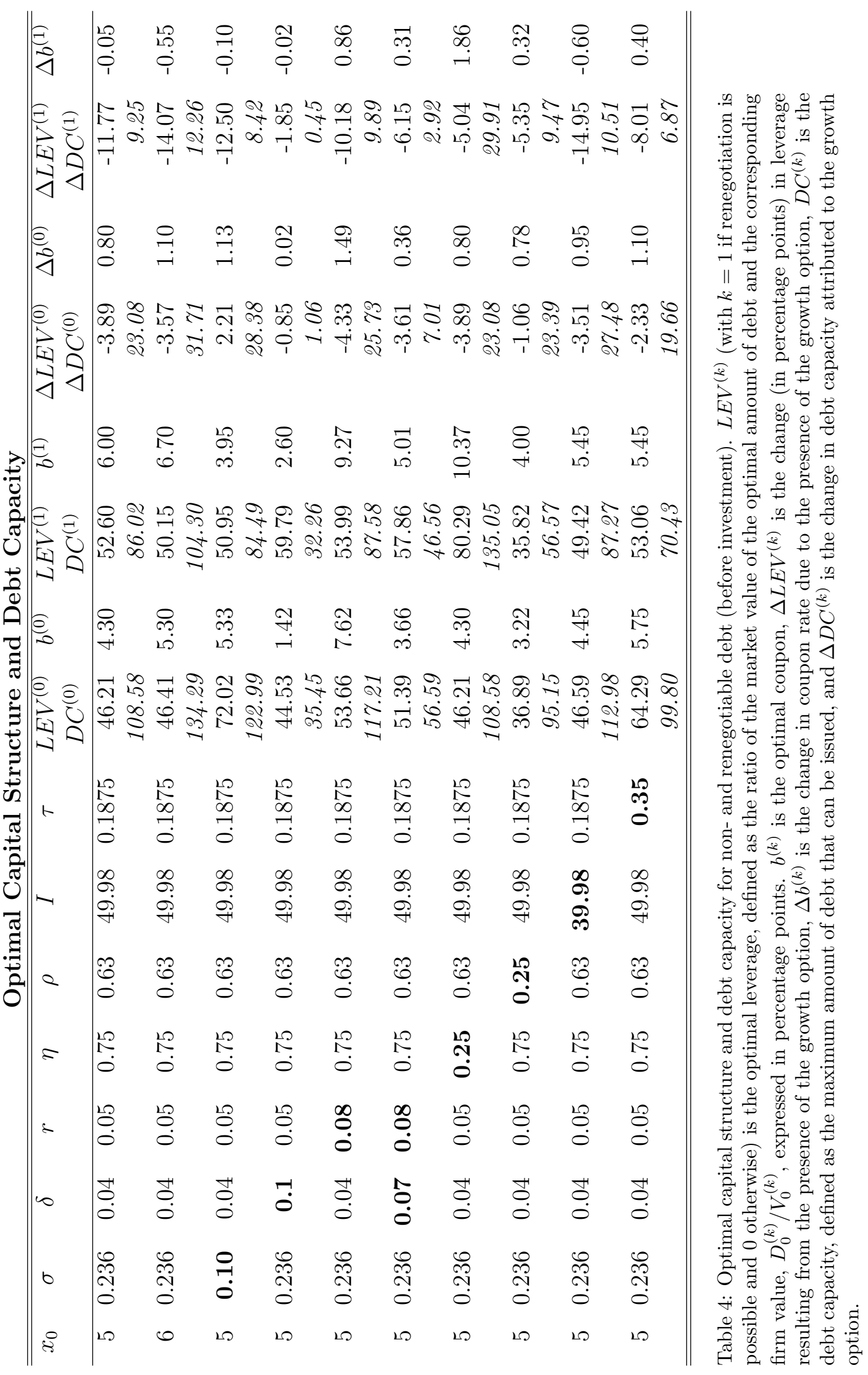




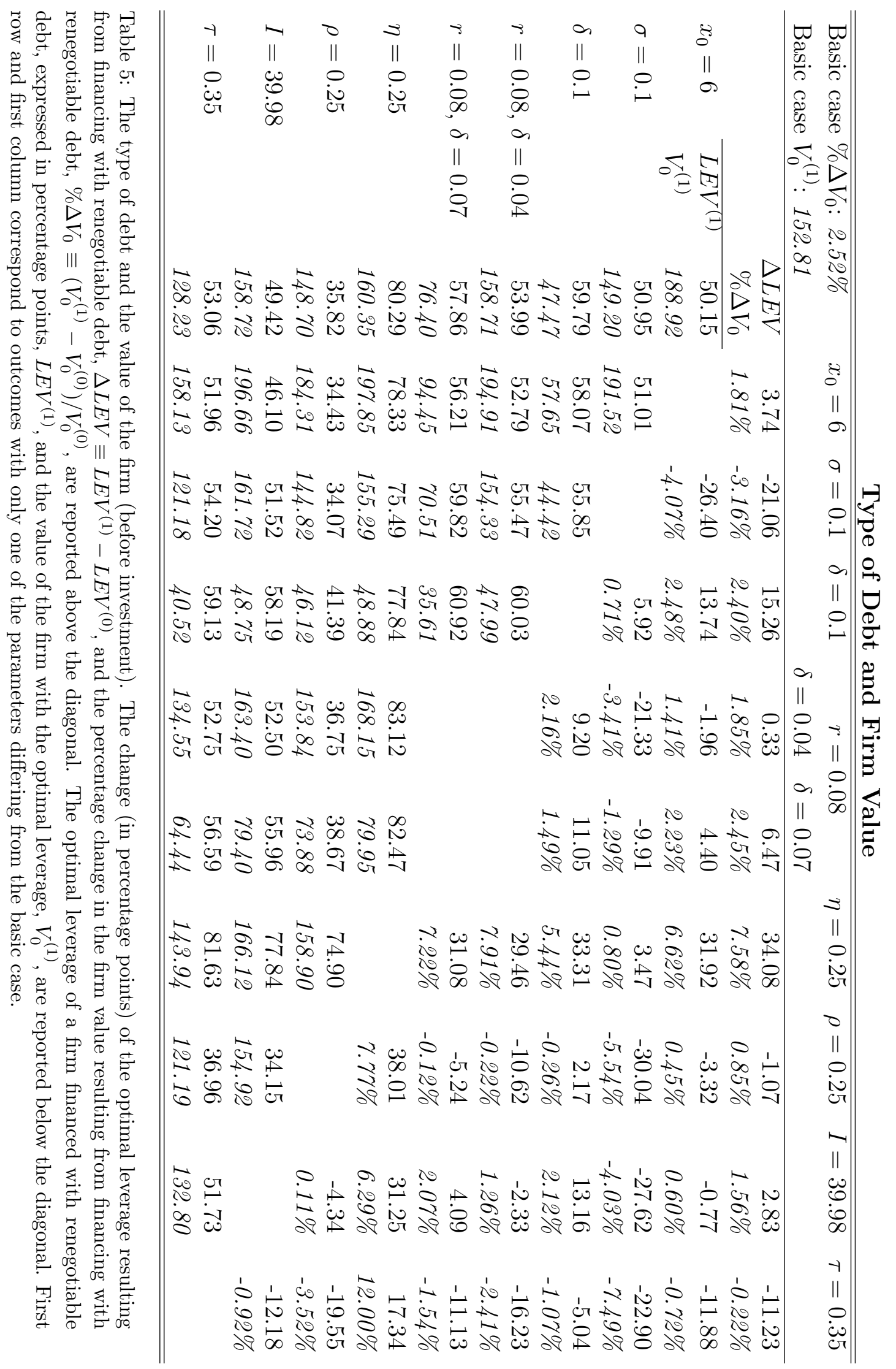


Valuation of the Firm's Claims when Debt Is Renegotiable

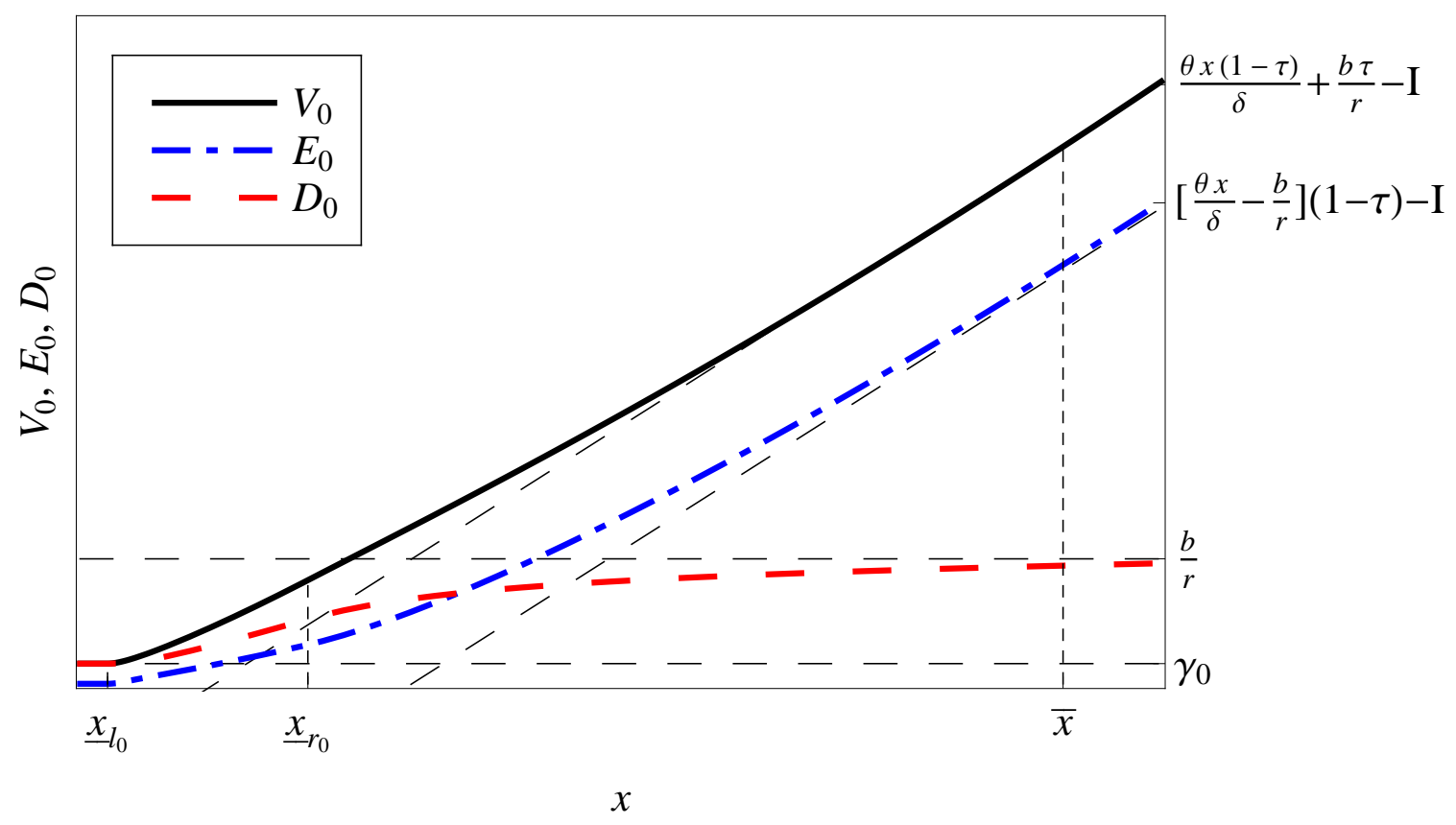

Figure 1: Value of the firm, $V_{0}$, its debt, $D_{0}$, and equity, $E_{0}$, before investment, with the shareholder's option to renegotiate the debt. $\underline{x}_{l_{0}}$ is the optimal liquidation trigger, $\underline{x}_{r_{0}}$ is the equityholders' renegotiation trigger, and $\bar{x}$ is the equity value-maximizing investment threshold. 


\section{Equityholders' Optimal Investment Thresholds}

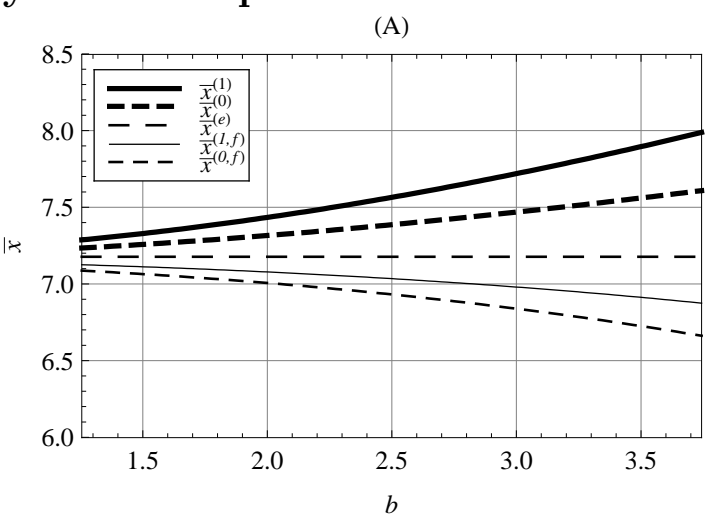

(B)

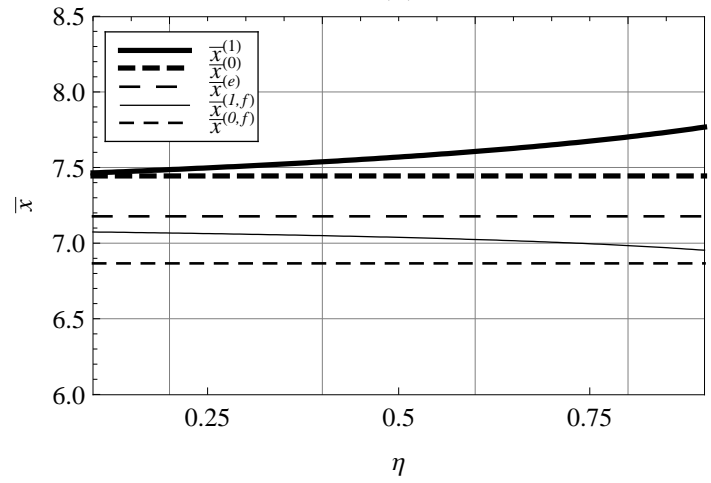

(C)

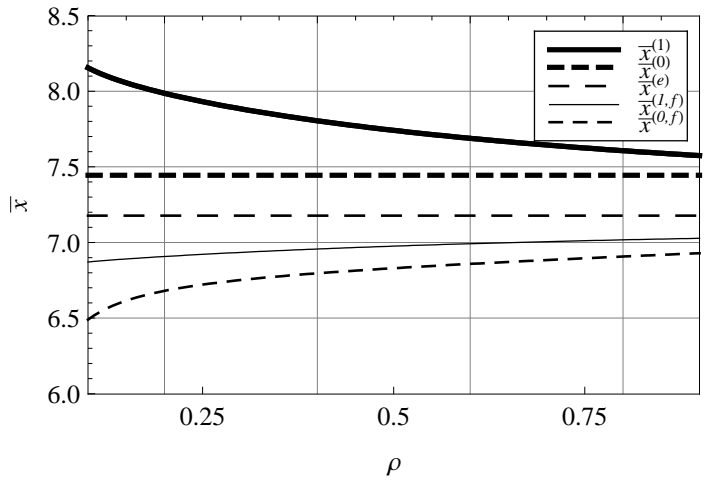

Figure 2: Optimal investment threshold as a function of coupon rate $b$, equityholders' bargaining power $\eta$, creditors' efficiency $\rho$, and interest rate $r . \bar{x}^{(1, f)}$ and $\bar{x}^{(1)}$ denote the firm and the equity value-maximizing threshold, respectively, in the presence of renegotiation option; $\bar{x}^{(0, f)}$ and $\bar{x}^{(0)}$ denote the firm and the equity value-maximizing threshold, respectively, for non-renegotiable debt. $\bar{x}^{(e)}$ is the all-equity firm investment threshold. 
Agency Cost of Debt and Incremental Debt Overhang
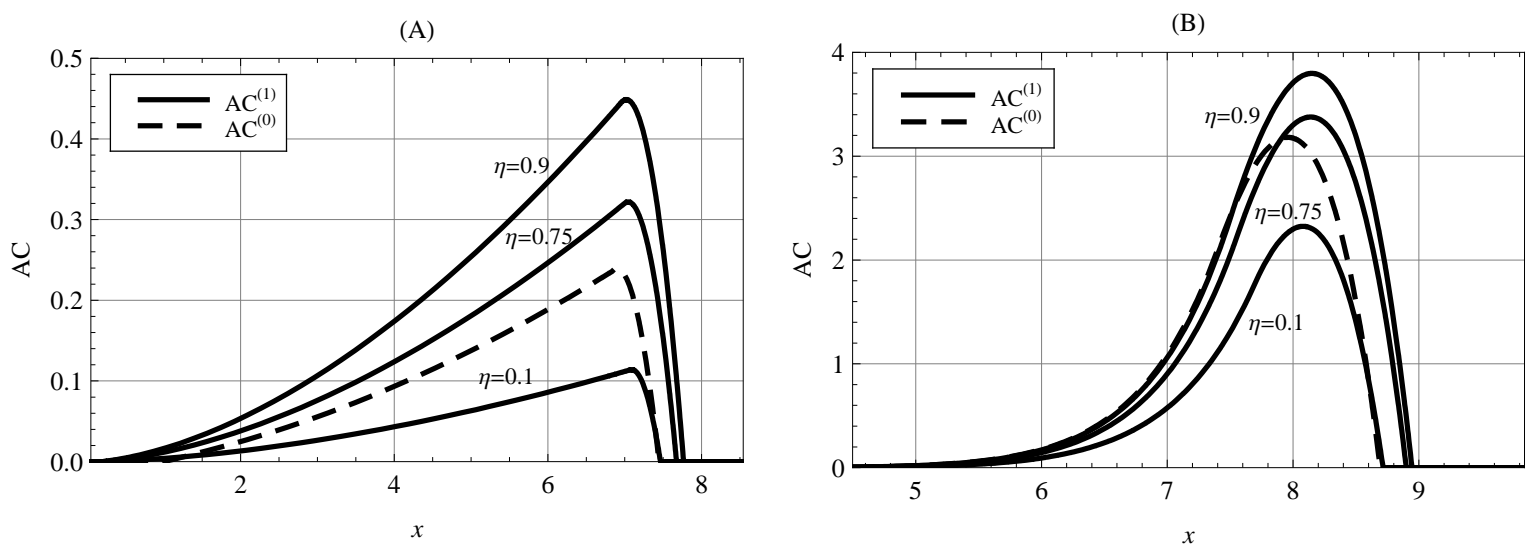

(C)
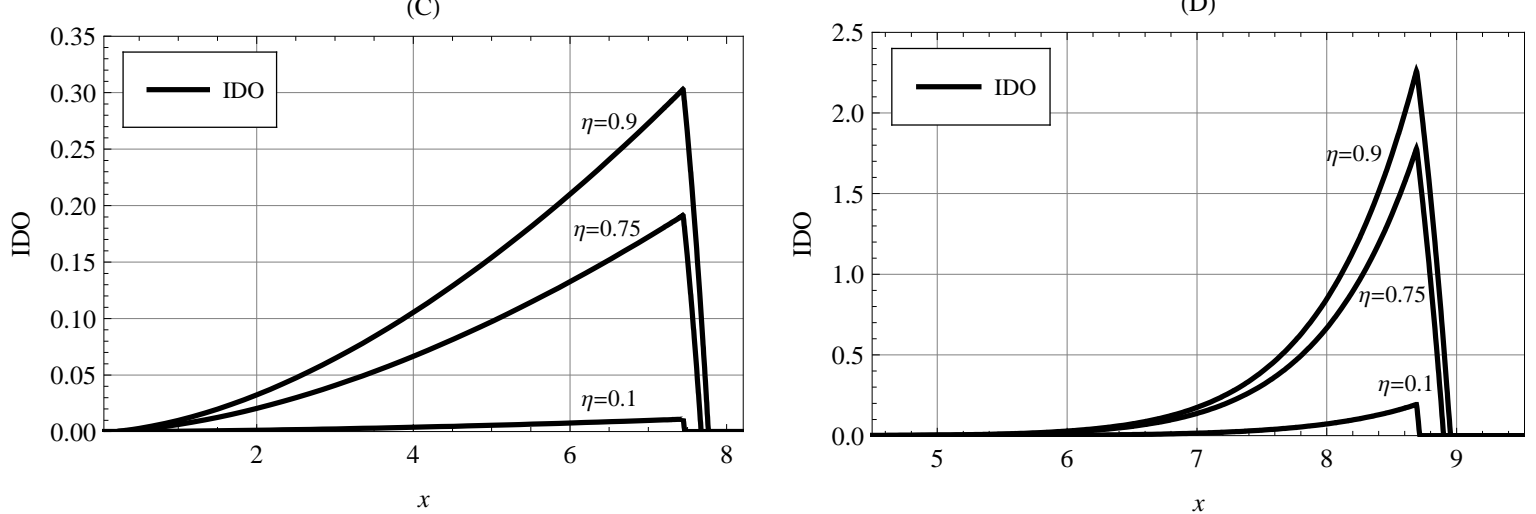

Figure 3: The agency cost of debt, $A C^{(0)}$ and $A C^{(1)}$, measured as the difference between the first-best and second-best value of the firm in the absence and in the presence, respectively, of the renegotiation option. Incremental debt overhang, IDO, measured as the value of the firm pursuing investment policy as with non-renegotiable debt and financed with renegotiable debt minus the value of the firm financed with renegotiable debt. $A C^{(0)}, A C^{(1)}$ and $I D O$ are calculated for different values of the equityholders' bargaining power parameter $\eta$ and varying levels of the cash flow process, $x$, for the basic set of parameter values (Panels $\mathrm{A}$ and $\mathrm{C}$ ) and for the negative growth-low volatility scenario, with $\delta=\sigma=0.1$ (Panels B and D). 